\title{
Mechanisms for the Formation of Domal and Basinal Detachment Faults: A Three-Dimensional Analysis
}

\author{
AN YIN
}

\author{
Department of Earth and Space Sciences, University of California, Los Angeles
}

\begin{abstract}
Detachment faults (i.e., regional low-angle normal faults) in metamorphic core complexes of the North American Cordillera commonly exhibit doubly plunging antiformal (domal) and synformal (basinal) geometries. These geometries have been previously attributed to the superposition of two processes: (1) the antiforms and synforms with axes parallel to the extension direction originated as primary fault undulations or corrugations developed coevally with fault slip, and (2) the antiforms and synforms with axes perpendicular to the extension direction were produced by isostatic uplift due to tectonic denudation. However, the coaxial relationship between undulations of detachment faults and the sedimentary beds and metamorphic foliations in both the upper and lower plates of some detachment fault systems in the U.S. Cordillera suggests that the synforms and antiforms with axes parallel to the extension direction may have formed as folds, and that the domal and basinal geometry of detachment faults may have formed synchronously by a single process. A three-dimensional, elastic thin plate model is developed to investigate possible mechanisms for the formation of domal and basinal detachment faults. This model explores the interactions among the vertical, horizontal, and basal shearing forces during the formation of warped detachment faults. The model considers the role of compression perpendicular to the extension direction and stress reduction parallel to the extension direction. The results of the model suggest that the stress reduction itself in the extension direction is insufficient to cause buckling of a thin elastic crust. Two mechanisms are most likely to explain the formation of domal and basinal geometries of detachment faults: (1) an upward pushing by undulatory crustal roots or buoyant synextensional plutons beneath the extensional belt, and (2) buckling caused by a compression perpendicular to the extension direction. Both mechanisms are consistent with the geologic constraints during the development of Cordilleran core complexes. In addition to isostatic uplift due to tectonic denudation, upward warping of detachment faults can also be caused by buckling, basal shearing, and buoyant forces.
\end{abstract}

\section{INTRODUCTION}

\section{General Background}

Cordilleran metamorphic core complexes are distinctive structural associations that consist of detachment faults (i.e., regional low-angle normal faults) juxtaposing brittlely extended rocks in an upper plate with ductilely stretched and sheared metamorphic and igneous rocks in a lower plate [Coney, 1980]. The detachment faults are commonly warped into doubly plunging antiforms (domes) and synforms (basins) with their major and minor axes parallel and perpendicular to the regional extension direction. The domal and basinal geometries of the detachment faults strongly control the distribution and exposures of the midcrustal rocks in the North American Cordillera that were uplifted during Cenozoic extension along detachment faults [Crittenden et al., 1980; Frost and Martin, 1982; Armstrong, 1982; Wernicke, 1985; Davis et al., 1986].

The origin of Cordilleran metamorphic core complexes is controversial. Coney [1980], Dickinson [1981], and Armstrong [1982], among others, proposed that the formation of the core complexes was directly related to interaction between the North American and Pacific plates. In contrast, Coney and Harms [1984], Sonder et al. [1987], and Wernicke et al. [1987] emphasized that instability of the overthickened crust formed during the Sevier-Laramide oro-

Copyright 1991 by the American Geophysical Union.

Paper number 91JB01113.

$0148-0227 / 91 / 91 \mathrm{JB}-01113 \$ 05.00$ genies was the major cause for the development of core complexes and Late Cenozoic extension in the North American Cordillera. These workers consider that the thick continental crust formed by the Mesozoic thrusting was gravitationally unstable and spread outward under its own weight. The initiation of spreading is attributed to either the reduction of viscosity by a mantle-derived heating event during midTertiary time [Coney, 1987] or the thermal relaxation of the overthickened crust [Sonder et al., 1987]. On the basis of an elastic model, Yin [1989a] suggested that the combined boundary and basal shearing forces due to plate interactions and the spreading of the weak middle and lower crust can explain the formation of regional low-angle normal faults in Cordilleran core complexes.

The initial dip of detachment faults in the Cordilleran core complexes has been hotly debated in the past few years. Observations of normal faulting in regions of active continental extension suggest that large seismogenic normal faults are restricted to dip angles of around $30^{\circ}-60^{\circ}$ [ Jackson and McKenzie, 1983; Jackson, 1987; Jackson and White, 1989]. However, a low-angle normal faulting event with a dip angle of possibly as low as $20^{\circ}$ was reported by Doser [1987] for the 1964 Ancash, Peru, earthquake in the high Andes of northern Peru. Contrary to the usual geometry of presently active normal faults in the world, field relationships in the North American Cordillera strongly suggest that most Cenozoic detachments are primary low-angle normal faults that initiated at dips of less than $30^{\circ}$ and root into the crust [Burchfiel et al., 1989; Davis and Lister, 1988; Lister and Davis, 1989; John, 1987; Reynolds and Spencer, 1985; Wernicke et al., 1985; Allmendinger et al., 1983]. 
The undulatory shape of low-angle detachment faults has been described in many core complexes of North America [Spencer, 1982, 1985; Davis et al., 1980, 1982; John, 1987; Davis and Lister, 1988]. Figure 1 shows the distribution of major domal and basinal detachment faults in the Colorado River Extensional Corridor [Howard and John, 1987] in southeastern California and western Arizona. The area has been systematically mapped in the past decade, and the geometry and kinematic evolution of detachment faults are well documented [Davis et al., 1980, 1982; Howard et al., 1982; John, 1982, 1987; Howard and John, 1987; Spencer, 1985; Spencer and Reynolds, 1990]. Major domal uplifts from north to south are the Dead Mountains antiform, Sacramento Mountains antiform, Chemehuevi Mountains antiform, Whipple Mountains antiform, Buckskin-Rawhide Mountains antiforms, and Harcuvar-Harquahala Mountains antiforms. Spacing between the major domal structures is about $35-60 \mathrm{~km}$, and the maximum amplitude is between 1 and $2 \mathrm{~km}$. The geometry of the detachment faults between the structural domes is basinal, because all dip away from the mountain ranges. Detailed correlations of detachment faults from mountain range to mountain range, however, remain problematic because the characteristics of the lower plate lithology and structures vary from place to place [cf. Davis and Lister, 1988; John, 1987]. Superimposed on each major domal detachment fault are numerous undulations or corrugations that trend parallel to the extension direction. These minor corrugations have shorter wavelengths (several hundreds of meters to several kilometers) and smaller amplitudes (several tens to a few hundred meters).

The Sacramento Mountains detachment fault in the northern part of the Colorado River Extensional Corridor (Figures 1 and 2a) was described in detail by Spencer [1985]. Overall, the northern half of the Sacramento Mountains is an antiform with a half wavelength of at least $10 \mathrm{~km}$ perpendicular to the extension direction and an amplitude of at least $350 \mathrm{~m}$. Figure $2 \mathrm{a}$ is a minimum-relief contour map of its basal detachment fault [Spencer, 1985]. This map is based on the fact that the preerosional elevation of eroded parts of the fault was at least as high as the exposed lower plate rocks, and the elevation of its buried parts is at least as low as the exposed upper plate rocks. Although this map does not represent the exact geometry of the fault because of poor constraints where the fault is eroded or buried, it nevertheless provides a general pattern of a warped detachment fault surface. The antiforms parallel or subparallel to the extension direction have a wavelength of about $3 \mathrm{~km}$ and an amplitude of about $100-200 \mathrm{~m}$.

The three-dimensional geometry of the detachment faults in the Chemehuevi Mountains was described by John [1987]. Figure $2 b$ shows cross-sectional views of the two major detachment faults, the lower and older Mohave Wash fault and the higher and younger Chemehuevi fault. John [1987] noted that undulations of the two faults have different amplitudes and wavelengths. Although John inferred the detachment fault undulations parallel to the extension direction as primary and coeval with fault slip, the observation itself does not preclude that the undulations are secondary and formed by folding. First, the two faults clearly developed at different times on the basis of crosscutting relationships [John, 1987] (Figure 2b). If the warping of the detachment faults had occurred during the entire phase of extension in the area, then the early warped detachment fault does not need to be concordant with the younger fault. Second, the two faults do not have to be exactly parallel, even though they were folded at the same time, because strict parallelism is only required if the folding mechanism is exclusively flexural slip. In fact, despite the disharmonic geometry of the two faults in detail, their dominant wavelengths are very consistent (Figure $2 b$ ), suggesting that the two faults may indeed have warped at the same time during their late stage of development.

In the Whipple Mountains, the synforms and antiforms with axes parallel to the extension direction in the lower plate of the Whipple detachment fault are defined by mylonitic foliation and sheetlike granitic plutons [Davis et al., $1980,1982]$. These axes coincide with the major or long axes of fault corrugations (Figure 2c). However, the mylonitic foliation generally dips $5^{0}$ to $25^{0}$ more steeply than the fault [Davis, 1988]. Davis and Lister [1989] attributed this discordance to multiple episodes of warping.

The relationship between warped detachment faults and bedding attitudes in its upper plates has important implications for the origin of the domal and basinal detachment faults. This relationship is, however, commonly obscured by multiple generations of normal faulting and associated tilting of strata in most core complexes. In addition, the magnitude of warping (less than $20^{\circ}$ ) is much less than the magnitude of tilting of the beds $\left(40-70^{\circ}\right)$ due to rotation along normal faults in the upper plates. Thus, to what degree the warping of detachment faults affected the attitudes of upper plate bedding is not always clear. Possible alternation of tilting of strata and warping of detachment faults during development of detachment fault systems is another factor that may further complicate the pattern of bedding attitudes in upper plates. Gently dipping, upper plate strata can change their strikes significantly by warping of detachment faults. For example, a bed dipping $30^{\circ}$ to the $\mathrm{N} 45^{\circ} \mathrm{E}$ direction changes its strike from $\mathrm{N} 45^{\circ} \mathrm{W}$ to $\mathrm{N} 76^{\circ} \mathrm{W}$ by a rotation of $20^{\circ}$ about a horizontal axis trending $N 45^{\circ} \mathrm{E}$. On the other hand, steeply dipping strata and upper plate high-angle normal faults change their strikes very little during warping of detachment faults. A bed dipping $60^{\circ}$ to the $\mathrm{N} 45^{\circ} \mathrm{E}$ direction changes its strike of $\mathrm{N} 45^{\circ} \mathrm{W}$ for only $9^{\circ}$ by a rotation of $20^{\circ}$ about a horizontal axis trending $N 45^{\circ} \mathrm{E}$. Such complex tilting history may have occurred in the Whipple Mountains area. Figure 2d is a structure map of the southernmost Whipple Mountains simplified from Dickey et al. [1980] which shows the relationship between the attitude of the Whipple detachment fault and the upper plate bedding attitudes measured from Miocene sedimentary rocks that consist of sandstone, conglomerate, siltstone, and limestone. In the westernmost part of the area the Whipple detachment fault dips to the southwest, and the strike of bedding is parallel to the strike of upper plate normal faults. The rotational history in this part of the area is probably simple, because the pattern of the bedding attitudes can be explained by rotation about an axis that is subparallel to the strike of the upper plate normal faults and the local strike of the detachment fault. This may not be the case, however, for the area to the east in the central and eastern parts of Figure 2d where the Whipple detachment fault dips to the south and southeast. The bedding above this segment of the detachment fault strikes in three dominant directions: northwest, east-west, and northeast. This pattern cannot be explained by rotation about a single axis. Instead, multiple 


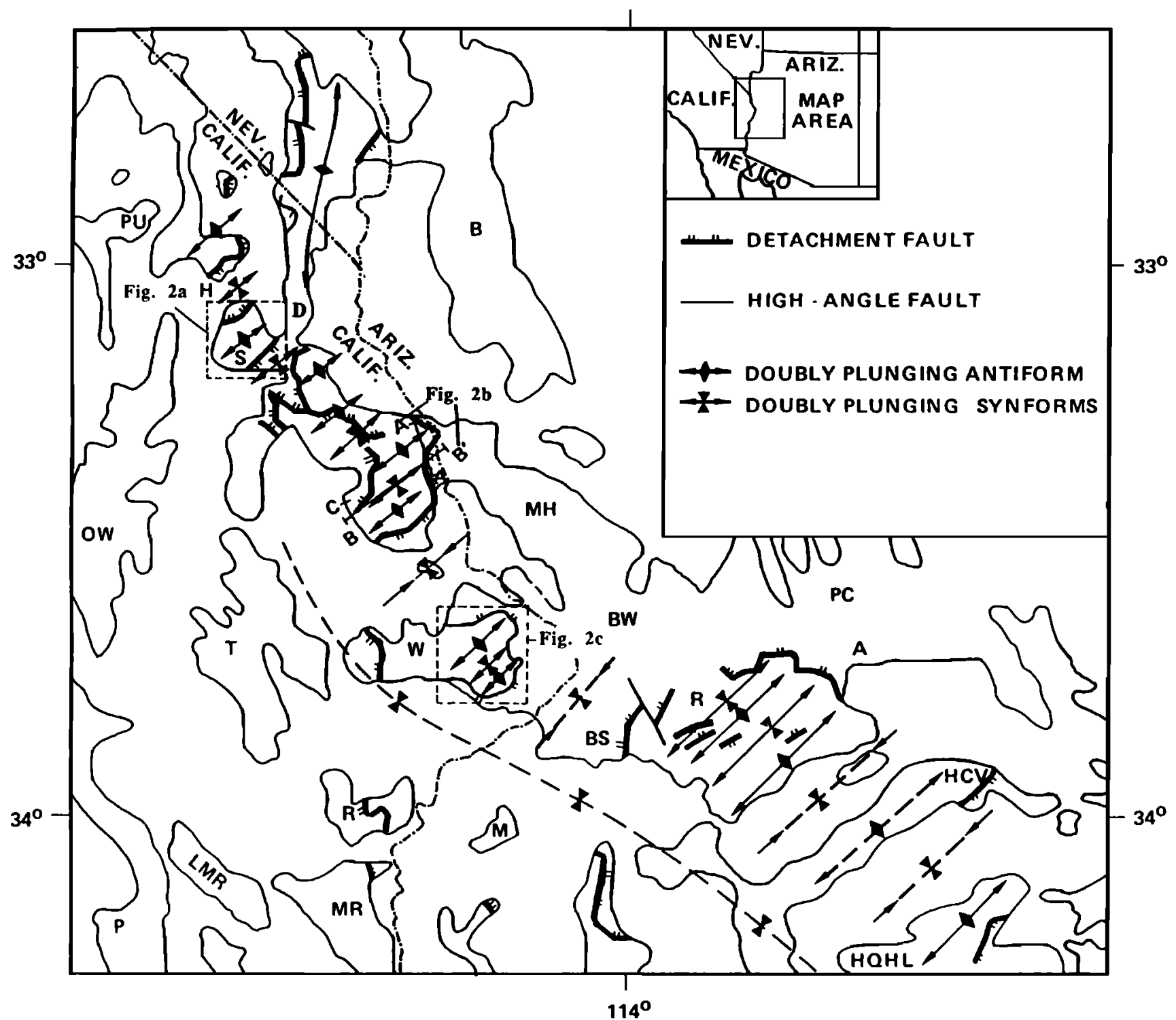

Fig. 1. Distribution of major detachment faults and antiforms and synforms in the Colorado River Extensional Corridor [Howard and John, 1987], southeastern California and western Arizona, modified from Spencer and Reynolds [1990], Davis et al. [1980, 1982], and John [1987]. A, Artillery Mountains; B, Black Mountains; BS, Buckskin Mountains; BW, Bill Williams Mountains; C, Chemehuevi Mountains; D, Dead Mountains; H, Homer Mountains; HCV, Harcuvar Mountains; HQHL, Harquahala Mountains; LMR, Little Maria Mountains; M, Moon Mountains; MH, Mohave Mountains; MR, Maria Mountains; OW, Old Woman Mountains; P, Palen Mountains; PC, Poachie Mountains; PU, Pjute Mountains; R, Rawhide Mountains; S, Sacramento Mountains; T, Turtle Mountains; W, Whipple Mountains. Locations of Figures 2a, 2c and cross sections AA' and BB' across the Chemehuevi Mountains in Figure 2b are also shown.

generations of rotations around multiple axes are required. The north west strike parallel to the strike of the upper plate normal faults is probably due to upper plate normal faulting. The east-west and northeast strikes are probably due to warping of the Whipple detachment fault that rotates the strike of the early tilted beds about an axis tending in the extension direction (NE-SW).

In the Weepah Hills area of southwestern Nevada the relationship between the warped Miocene Weepah Hills detachment fault and the beds of the Miocene Esmeralda Formation in its upper plate is well preserved due to a relatively smaller amount of upper plate extension [Stewart and Diamond, 1990]. The Miocene Esmeralda strata are gently folded, and the fold axes coincide with the corrugations of the Weepah detachment fault. The possible effect of warp- ing of detachment faults on the attitudes of upper plate bedding (Figure 2d) and coaxiality of folds in sedimentary beds [Stewart and Diamond, 1990], antiforms and synforms of foliations and sheetlike plutons (Figure 2c), and undulations of detachment faults suggest, or at least do not preclude, that the fault corrugations parallel to the extension direction formed by folding of originally more planar surfaces.

Mechanisms for the Formation of the Domal and Basinal Detachment Faults

Rehrig and Reynolds [1980], Hyndman [1980], and Howard et al. [1982], among others, proposed that the antiformal uplift of core complexes perpendicular to the extension direction occurs as an isostatic response to tectonic denudation. 


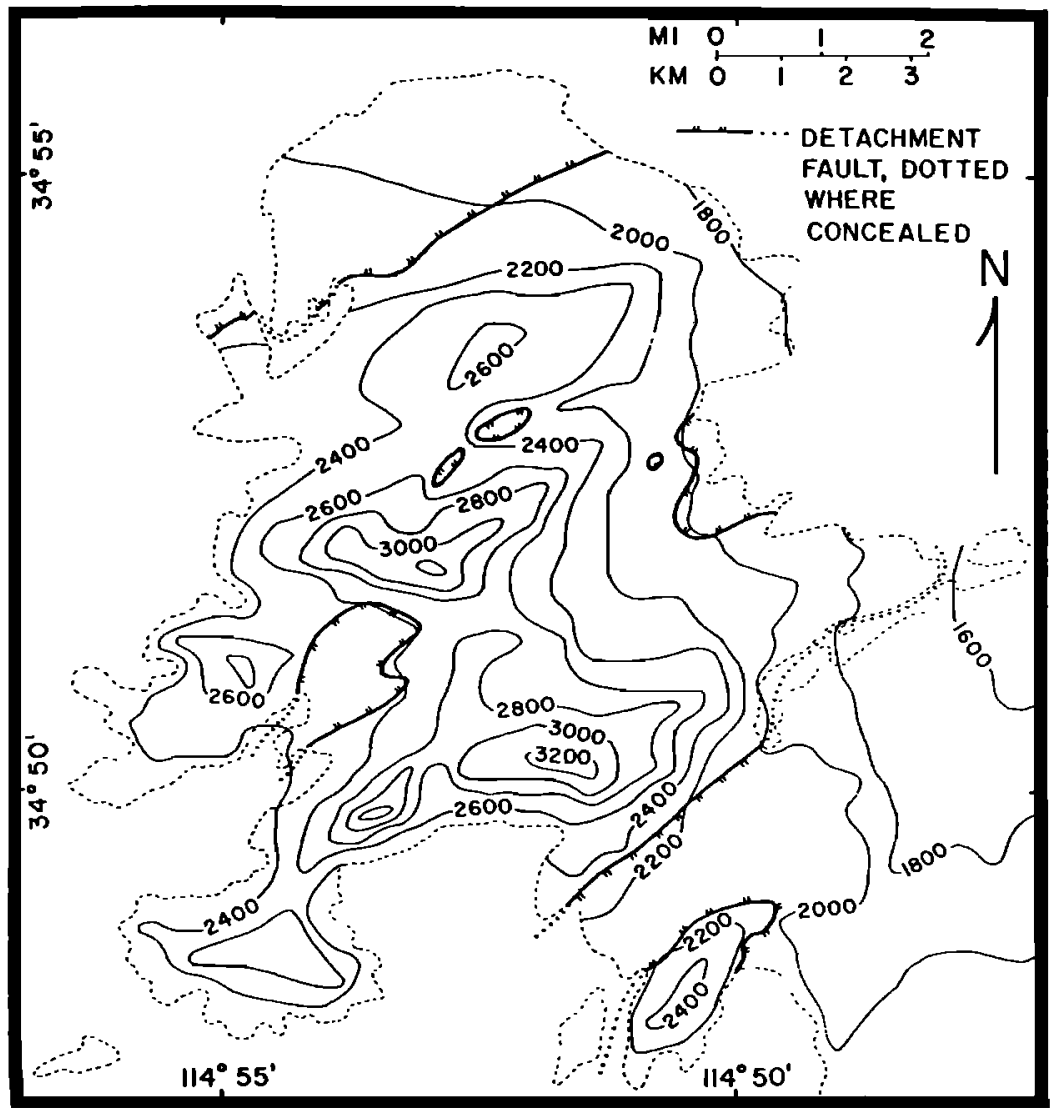

Fig. 2a. Minimum structural contour map of the Sacramento Mountains detachment fault, northern Sacramento Mountains [after Spencer, 1984]. Contour interval, 200 feet $(60 \mathrm{~m})$.
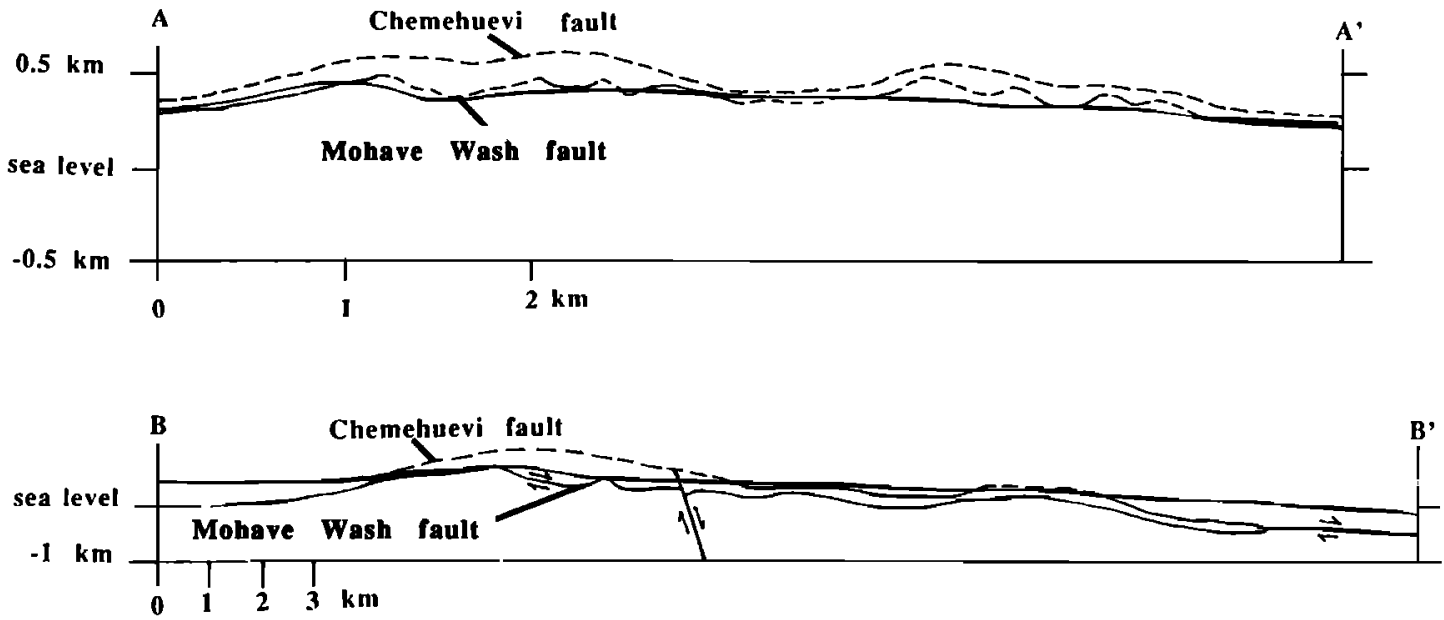

Fig. 2b. Geologic cross sections of Chemehuevi Mountains showing geometry of Chemehuevi and Mohave Wash detachment faults [after John, 1987]. See Figure 1 for location.

Spencer [1984] modeled this process assuming zero flexural rigidity of the lithosphere. The concept of tectonic denudation resulting in isostatic uplift of an extended area was first proposed by Vening Meinesz [1950] during his study of the origin of the rift shoulder along the East African rift. This mechanism has been widely accepted and used as a possible mechanism to explain the evolution of detachment fault systems [e.g., Davis and Lister, 1988; Wernicke, 1985; Wernicke and Axen, 1988; Hamilton, 1988; Lister and Davis, 1989; Buck, 1988]. Assuming that the lithosphere retains lateral strength during extension, Weissel and Karner [1989] investigated the isostatic consequences of instantaneous slip on a normal fault. In their model, isostatic equilibrium and uniform crustal thickness are assumed before extension. Thus no extra buoyant forces and in-plane stresses except the isostatic restoring force were considered for their model.

One problem with the Vening Meinesz model in explaining the domal and basinal geometry of detachment faults is that it requires differential amounts of extensional denudation above the basinal and domal parts of a detachment 


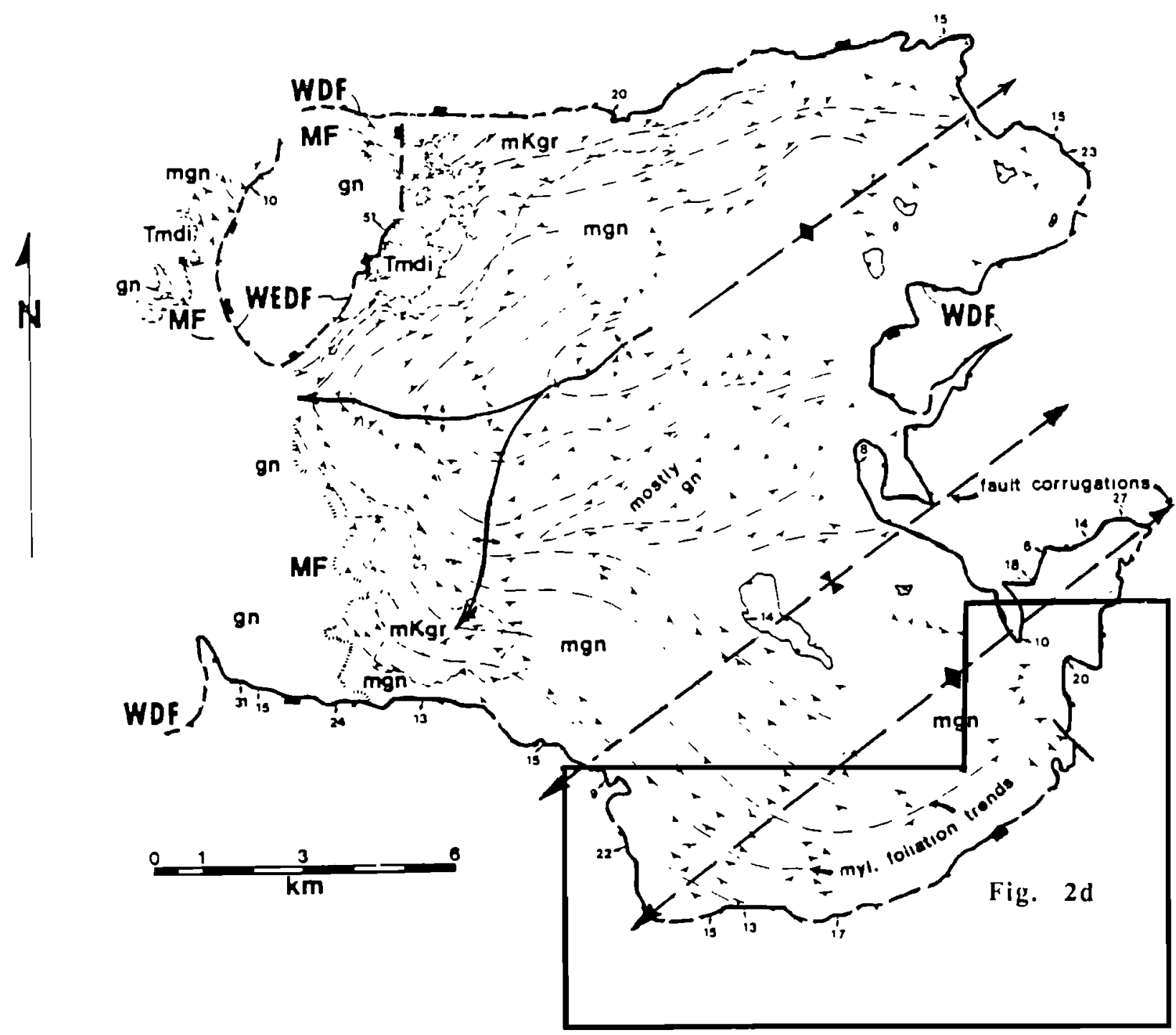

Fig. 2c. Geologic map showing geometry of Whipple detachment fault (WDF) and its structural relationship with mylonitic foliation below the Whipple mylonitic front (MF) in its lower plate [after Davis, 1988]. Foliation trends are shown in mylonitic gneisses (mgn) and a mylonitized composite Cretaceous granitic pluton (mKgr). Nonmylonitized gneisses (gn) structurally overlie the mylonitic front, which is intruded by a Miocene dioritic pluton. War Eagle detachment fault (WEDF) offsets the mylonitic front ca. $4.5 \mathrm{~km}$ in a N30 ${ }^{\circ} \mathrm{E}$ direction.

fault. However, such a differential extension along an extensional belt in the North American Cordillera has not yet been demonstrated anywhere. Another problem with the Vening Meinesz model is that the extended area can never be uplifted above the unextended area by isostatic rebound. Holt et al. [1986] pointed out that even with zero flexural rigidity, Spencer's model, which is similar to the Vening Meinesz model, does not explain how a core complex uplift can exceed the elevation of adjacent unextended areas, as observed in the Santa Catalina-Rincon Mountains core complexes in southwestern Arizona. They proposed that the uplift of core complexes may have been related to the superposition of two processes: (1) regional, low-relief, isostatic uplift over a crustal root in response to tectonic denudation by detachment faulting, and (2) complete local isostatic uplift during and after later high-angle normal faulting. Holt et al. [1986] calculated the flexure of an elastic plate due to a distributed vertical load from below, based on twodimensional elastic plate theory. They attributed the vertical load to an uncompensated buoyant crustal root emplaced in the mantle. Block and Royden [1990] showed that flexural uplift of midcrustal detachment faults requires not only local thinning of the hanging wall of a detachment fault, but also a significant (3-5 km) local reduction in topographic relief over the domal part of the detachment fault, a reduction that they considered to be geologically unreasonable.

There are two major problems with the aforementioned theoretical models [Yin, 1989b]: (1) all are two-dimensional and intended to explain only the geometry of domal detachment faults in a cross-sectional view parallel to the extension direction, and (2) they do not consider the role of the horizontal forces perpendicular to the extension direction or the geometry of an extensional belt in the formation of domal and basinal detachment faults. The incomplete quantitative modeling and emphasis on upwarped detachment faults may be attributed to the extensive publications of cross sections across domal parts of detachment faults which are commonly best exposed.

Jackson and White [1989] noticed that large continental normal-slip earthquakes commonly involve faulting in seg- 


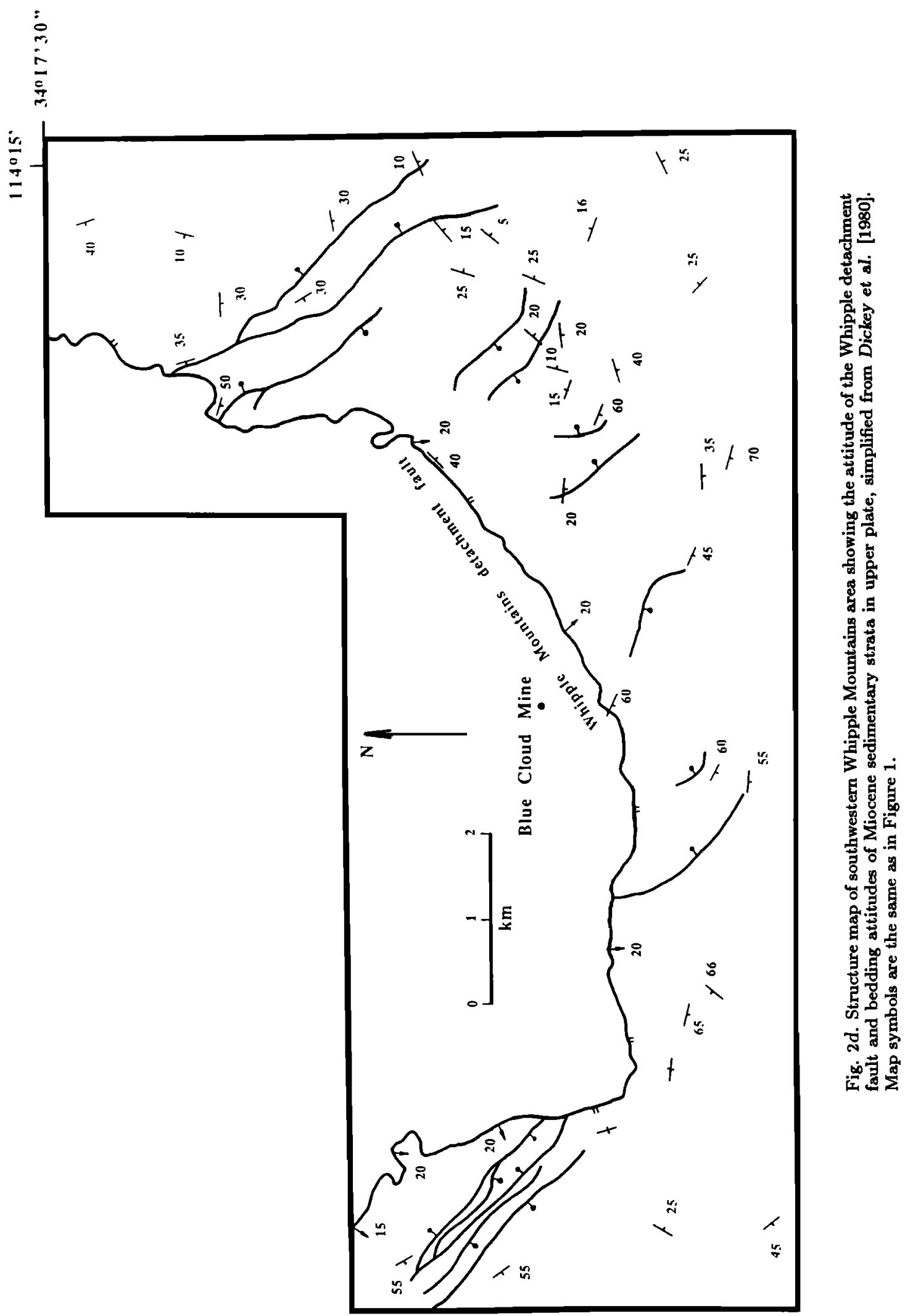


ments of up to about $20 \mathrm{~km}$ in length, which are either arranged en echelon separated by gaps, or involve dramatic changes in strike along the length of the rupture zone. They proposed that the antiforms and synforms of detacliment faults in the North American Cordillera reflect the primary geometry of the detachment faults. If this proposal is correct, then the coaxiality of warped sedimentary beds, foliation and sheetlike plutons, and detachment faults should not be expected, contradicting the observations.

Spencer [1982] attributed the antiforms and synforms with axes parallel to the extension direction as folds due to reduction of the compressive stress in the extension direction during the extension. John [1987] proposed that the domal geometry of detachment faults results from the superposition of two processes: (1) the antiforms and synforms with axes parallel to the extension direction developed coevally with fault slip as primary undulations of fault surfaces, that is, fault corrugations, and (2) the antiforms and syuforms with axes perpendicular to the extension direction were caused by an isostatic response to the denudation by detachment faulting. John [1987] inferred that the fault corrugations are equivalent to mullion structures. Descriptively, a mullion is a corrugation along the interface between a competent and an incompetent layer [Wilson, 1953; Ramsay, 1967; Hobbs et al., 1976]. Although mullions are commonly found on one interface only, Smith [1975, p. 1608] suggested that they originated as one of two interfaces bounding larger pinchand-swell structures. The theory of the formation of mullions in both Newtonian and non-Newtonian materials was developed by Smith [1975, 1977, 1979] and Fletcher [1982]. It provides a quantitative relationship between the dominant normalized wavelength of mullions (the ratio of wavelength and thickness of the incompetent layer) and the ratio of viscosities of the competent layer and incompetent layer. This theory may not be applicable to explain the formation of domal and basinal detachment faults for two reasons. First, the theory only concerns the instability caused by variations of viscosity under action of an applied stress and ignores the effect of density contrast on gravitational instability. Thus it is only appropriate to explain structures on scales of 1 km or less [Smith, 1977]. The tectonic history of the North American Cordillera suggests that variations in density due to earlier compression and synextensional plutonism are important in development of core complexes [e.g., Coney and Harms, 1984; Sonder et al., 1987]. Second, because detachment faults are brittle features and their warping is involved in some areas of unmetamorphosed sedimentary rocks [e.g., Stewart and Diamond, 1990], the warping may have occurred at shallow crustal levels above a brittle-plastic transition zone where the rheology of the crust is best described as an elastic-brittle material [Chen and Molnar, 1983].

To understand the mechanisms responsible for low-angle detachment faults, the following questions need to be addressed. Why did wavelike domal uplifts occur during core complex extension? Was the pattern of uplifts controlled by a vertical force due to an uncompensated crustal root or buoyant pluton or by the horizontal compression perpendicular to extension? Did the shape of an extensional belt control the geometry and magnitude of the domal and basinal deflection of detachment faults? What is the role of ductile flow in the lower crust in warping detachment faults? A three-dimensional thin plate model is developed in this study to address these questions. The goal of this modeling is to explore the interactions of different model parameters.

The following major assumptions are made. First, I assume that the upper crust can be approximated as an elastic solid with a uniform thickness. I also assume that the geometry of an extended belt, for example, the lower Colorado River Extensional Corridor (Figure 1), can be approximated as a rectangular belt on plan view. Thus the results of the model should be regarded only as a conceptual guide to understand the warping mechanism(s) of detachment faults rather than as the final answers to the problem. It is the first step, however, in understanding the physics of the system.

\section{Model and Results}

Let us consider a thin plate and choose a fixed righthanded rectangular Cartesian frame of reference with the $x y$ plane coinciding with the middle plane of the plate and the $z$ axis normal to it (Figure 3a). Normal and shear stress components in the $x, y$, and $z$ directions are shown in Figures $3 b$ and $3 c$. The sign convention in my calculations follows that of elasticity, that is, tensile stress is positive. The governing equation for deflection of a thin elastic plate due to combined vertical, horizontal, and basal shearing tractions in three dimensions [Fung, 1965] is

$$
\begin{gathered}
\frac{\partial^{4} w}{\partial x^{4}}+2 \frac{\partial^{4} w}{\partial x^{2} \partial y^{2}}+\frac{\partial^{4} w}{\partial y^{4}}=\frac{1}{D}\left[q(x, y)+N_{x}(x, y) \frac{\partial^{2} w}{\partial x^{2}}\right. \\
+2 N_{x y}(x, y) \frac{\partial^{2} w}{\partial x \partial y}+N_{y}(x, y) \frac{\partial^{2} w}{\partial y^{2}} \\
\left.+\frac{\partial m_{x}(x, y)}{\partial x}+\frac{\partial m_{y}(x, y)}{\partial y}-f_{x}(x, y) \frac{\partial w}{\partial x}-f_{y}(x, y) \frac{\partial w}{\partial y}\right]
\end{gathered}
$$

where $w$ is deflection normal to the $x y$ plane and $D$ is the flexural ridigity

$$
D=\frac{E h^{3}}{12\left(1-\nu^{2}\right)}
$$

where $h$ is the thickness of the elastic plate, $E$ is Young's modulus, and $\nu$ is Poisson's ratio. The terms $N_{x}, N_{y}$, and $N_{x y}$ (forces per unit length) in equation (1) are the stress resultants in the $x$ and $y$ directions acting on the middle plane $z=0$ of the thin plate (Figure $3 b$ ). They are related to the stress components (Figure $3 c$ ) by

$$
\begin{gathered}
N_{x}=\int_{-h / 2}^{h / 2}\left(\sigma_{x x}-\sigma_{z z}\right) d z \\
N_{x y}=\int_{-h / 2}^{h / 2} \sigma_{x y} d z \\
N_{y}=\int_{-h / 2}^{h / 2}\left(\sigma_{y y}-\sigma_{z z}\right) d z \\
N_{z}=\int_{-h / 2}^{h / 2}\left(\sigma_{z z}-\sigma_{z z}\right) d z=0
\end{gathered}
$$

where $\sigma_{x x}$ and $\sigma_{y y}$ are the horizontal normal stress components in the $x$ and $y$ directions and $\sigma_{z z}$ is the vertical normal stress component in the $z$ direction. Stress resultants 
$N_{x}$ and $N_{y}$ are so defined that the influence of lithostatic stresses is removed. Thus, the deflection $w$ defined in equation (1) is produced only by tectonically induced deviatoric stresses. The terms $f_{x}$ and $f_{y}$ in equation (1) represent external loading tangential to the middle plane $z=0$ of the plate and are defined by the following relationships:

$$
\begin{gathered}
f_{x}=\sigma_{z x}\left(\frac{h}{2}\right)-\sigma_{z x}\left(-\frac{h}{2}\right)+\int_{-h / 2}^{-h / 2} X d z \\
f_{y}=\sigma_{z y}\left(\frac{h}{2}\right)-\sigma_{z y}\left(-\frac{h}{2}\right)+\int_{-h / 2}^{h / 2} Y d z
\end{gathered}
$$

where $X$ and $Y$ are the components of a body force in the $x$ and $y$ directions. The terms $m_{x}$ and $m_{y}$ in equation (1) are the resultant external moment per unit area about the middle plane, and are defined by

$$
\begin{aligned}
& m_{x}=\frac{h}{2}\left[\sigma_{z x}\left(\frac{h}{2}\right)-\sigma_{z x}\left(-\frac{h}{2}\right)\right]+\int_{-h / 2}^{h / 2} z X d z \\
& m_{y}=\frac{h}{2}\left[\sigma_{z y}\left(\frac{h}{2}\right)-\sigma_{z y}\left(-\frac{h}{2}\right)\right]+\int_{-h / 2}^{h / 2} z Y d z
\end{aligned}
$$

The term $q(x, y)$ in equation (1) is the vertical load normal to the middle plane (Figure $3 a$ ).

In situ stress measurements at shallow crustal levels [McGarr and Gay, 1978] suggest that the stress components in the vertical and horizontal directions are linear functions of depth. If we assume that this relationship holds throughout the crust, then the state of stress in the crust may be expressed as

$$
s \sigma_{x x}=t \sigma_{y y}=\sigma_{z z}=-\rho_{c} g\left(\frac{h}{2}-z\right)
$$

or

$$
\begin{aligned}
\sigma_{x x} & =\alpha \sigma_{z z} \\
\sigma_{y y} & =\beta \sigma_{z z}
\end{aligned}
$$

where $\rho_{c}$ is the density of the crust and $s, t, \alpha$ and $\beta$ are constants. Using (3a) and (3c), we can calculate the tractions along the edges of the plate as

$$
\begin{aligned}
& N_{x}=\frac{1}{2}(1-\alpha) \rho_{c} g h^{2} \\
& N_{y}=\frac{1}{2}(1-\beta) \rho_{c} g h^{2}
\end{aligned}
$$

Without tectonic disturbance, the lithosphere is under lithostatic stress [McGarr, 1988], that is, all three stress components are equal and compressive. We have

$$
\begin{gathered}
\sigma_{x x}=\sigma_{y y}=\sigma_{z z}=-\rho_{c} g\left(\frac{h}{2}-z\right) \\
N_{x}=N_{y}=N_{z}=0
\end{gathered}
$$

If we choose the $x$ and $y$ axes parallel and perpendicular to the extension direction, respectively, and set $N_{x y}=0$, then the $x$ and $y$ directions are the directions of the principal stresses. We consider that the lower crust is inviscid. This implies that $\sigma_{z y}(-h / 2)=\sigma_{z x}(-h / 2)=0$. Because $\sigma_{z x}(h / 2)=\sigma_{z y}(h / 2)=0$ at the Earth's surface and the body force components $X$ and $Y$ in the $x$ and $y$ directions

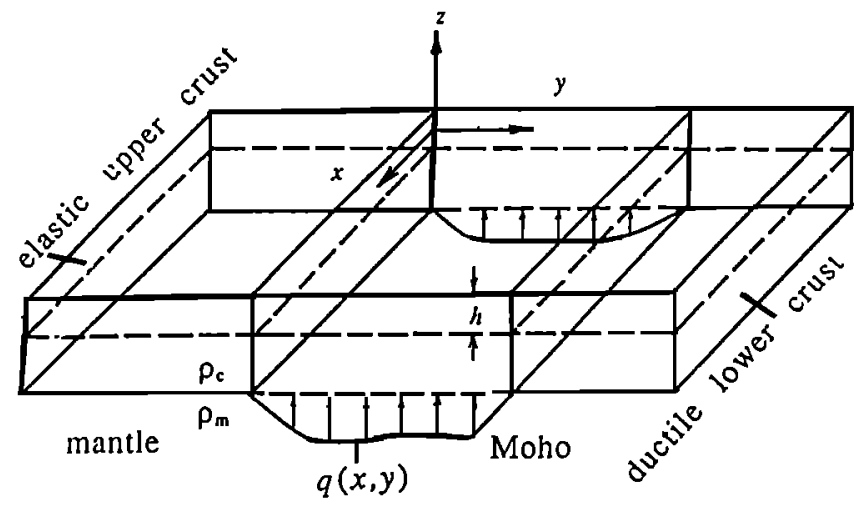

a

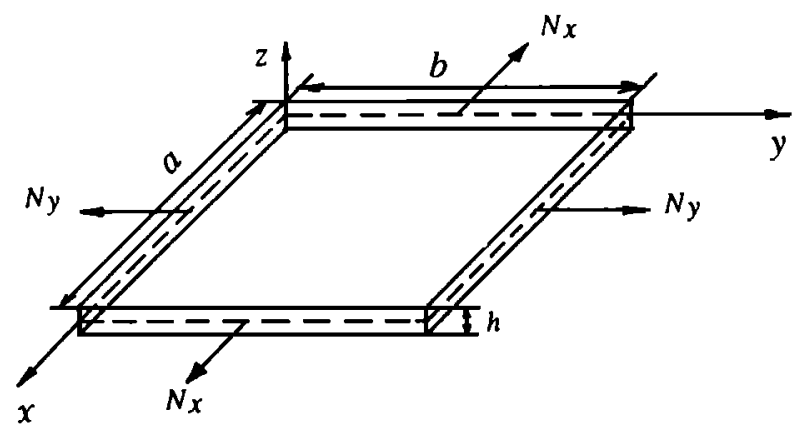

b

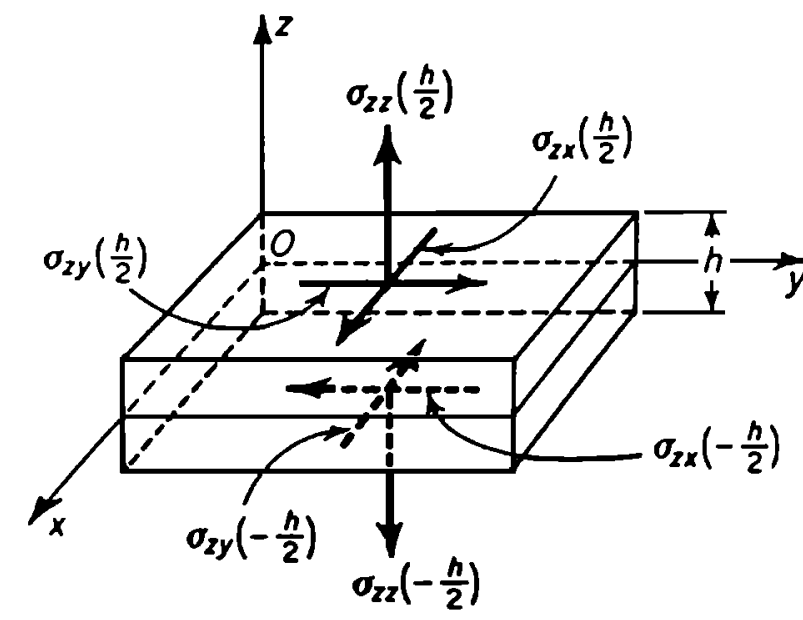

c

Fig. 3. Notations of external loads, stress components, and framework of reference. a Coordinate system used in the calculation. The origin is located on the middle surface of the assumed elastic upper crust. $h$ is the thickness of the upper crust; $q(x, y)$ is the vertical force due to an uncompensated crustal root; the $\boldsymbol{x}$ axis is parallel to the extensional belt; the $y$ axis is parallel to the extension direction; $\rho_{c}$ is the density of the crust; $\rho_{m}$ is the density of the mantle. $b$ Stress resultants $N_{x}$ and $N_{y}$ as defined in the text in the $x$ and $y$ directions. $a$, length of plate; $b$, width of plate; $h$, thickness of plate. $c$ Normal and shear stress components on the top and base of the plate in the $x, y$, and $z$ directions. 
can be ignored, we have $f_{x}=f_{y}=m_{x}=m_{y}=0$. The boundary conditions along the edges of the plate are those of simple support, that is,

$$
\begin{gathered}
(w)_{x=0, x=a}=(w)_{y=0, y=b}=0 \\
\left(\frac{\partial^{2} w}{\partial x^{2}}+\nu \frac{\partial^{2} w}{\partial y^{2}}\right)_{x=0, x=a}=\left(\frac{\partial^{2} w}{\partial x^{2}}+\nu \frac{\partial^{2} w}{\partial y^{2}}\right)_{y=0, y=b}=0
\end{gathered}
$$

where $a$ and $b$ are the width and length of the plate, respectively. These conditions imply that the deflections of the edges of the plate are zero and that the plate along the edges can be rotated freely. The latter is the result of the assumption that the lower crust is inviscid.

In general, under the boundary conditions expressed in equation (9), the solution of (1) can be obtained as (Appendix A)

$$
w=\sum_{m=1}^{\infty} \sum_{n=1}^{\infty} A_{m n} \sin \left(\frac{m \pi x}{a}\right) \sin \left(\frac{n \pi y}{b}\right)
$$

and

$$
\begin{gathered}
A_{m n}=\left[4 \int_{0}^{a} \int_{0}^{b} q(x, y) \sin \left(\frac{m \pi x}{a}\right) \sin \left(\frac{n \pi y}{b}\right) d x d y\right] \\
/\left\{a b D \pi ^ { 4 } \left[\left(\frac{m^{2}}{a^{2}}+\frac{n^{2}}{b^{2}}\right)^{2}\right.\right. \\
\left.\left.+\frac{6 \rho_{c} g\left(1-\nu^{2}\right)}{E h \pi^{2}}\left((1-\alpha) \frac{m^{2}}{a^{2}}+(1-\beta) \frac{n^{2}}{b^{2}}\right)\right]\right\}
\end{gathered}
$$

where $m$ and $n$ are half wavenumbers. If the distribution of the vertical load $q(x, y)$ is known, then $A_{m n}$ is uniquely determined. Assuming that the vertical load $q(x, y)$ is due to an uncompensated crustal root emplaced in the upper mantle (Figure 3a), then the distribution of the buoyant force depends on the geometry of the crustal root, that is,

$$
q(x, y)=\sigma_{z z}(-h / 2)=\left(\rho_{m}-\rho_{c}\right) g d(x, y)
$$

where $d(x, y)$ defines the geometry of the uncompensated crustal root and is measured from the average depth of the Moho to the depth where the density contrast is zero. The vertical load can also be induced by a buoyant pluton rising upward. The magnitude of the upward vertical force depends on the density contrast between the pluton and the adjacent rocks as well as the geometry of the pluton. The effect of plutons will not be quantitatively discussed here. However, results from the assumed vertical load due to crustal roots provide the same conceptual guide to how the distribution of buoyant forces influences the deflection of a thin elastic crust.

Equation (10b) shows how the deflection of an elastic crust depends on the state of in-plane stresses as represented by the parameters $\alpha$ and $\beta$. For instance, if the plate is compressed in both the $x$ and $y$ directions and $\alpha>1$ and $\beta>1$, then the denominator in equation (10b) may be equal to zero:

$$
\begin{gathered}
\left(\frac{m^{2}}{a^{2}}+\frac{n^{2}}{b^{2}}\right)^{2} \\
+\frac{6 \rho_{c} g\left(1-\nu^{2}\right)}{E h \pi^{2}}\left[(1-\alpha) \frac{m^{2}}{a^{2}}+(1-\beta) \frac{n^{2}}{b^{2}}\right]=0
\end{gathered}
$$

which is the condition for buckling. This condition can be achieved by either gradually increasing the values of $\alpha$ and $\beta$, or by decreasing the thickness of the elastic crust $h$. This relationship has an important geologic implications for crustal extension and detachment fault warping. For example, the crustal thickness may gradually decrease during extension, although the state of crustal stress reamins. Eventually, the crust is so thin that the buckling condition shown in $(10 b)$ can be reached. This physical concept predicts that warping of detachment faults due to buckling should occur during its later stage. Another mechanism that can reduce the crustal thickness is thermal heating, which was intimately related to the development of Cordilleran core complexes.

Now let us consider that the thin plate is extended in the $y$ direction due to stress reduction, that is, the stress in the $y$ direction $\sigma_{y y}$ is reduced with respect to the lithostatic stress, and the stress components in the $x$ and $z$ directions remain the same and equal to the lithostatic stress (i.e., $\alpha=1$ and $0<\beta<1$ ), then equation (10b) can be simplified to

$$
A_{m n}=\frac{4 \int_{0}^{a} \int_{0}^{b} q(x, y) \sin \left(\frac{m \pi x}{a}\right) \sin \left(\frac{n \pi y}{b}\right) d x d y}{a b D \pi^{4}\left\{\left(\frac{m^{2}}{a^{2}}+\frac{n^{2}}{b^{2}}\right)^{2}+\frac{6 \rho_{c} g\left(1-\nu^{2}\right)}{E h \pi^{2}}\left[(1-\beta) \frac{n^{2}}{b^{2}}\right]\right\}}
$$

In this case, buckling can never occur, and $A_{m n}$ is always positive because $(1-\beta)<1$. Thus

$$
\left(\frac{m^{2}}{a^{2}}+\frac{n^{2}}{b^{2}}\right)^{2}+\frac{6 \rho_{c} g\left(1-\nu^{2}\right)}{E h \pi^{2}}\left[(1-\beta) \frac{n^{2}}{b^{2}}\right]>0
$$

The above relationships imply that the sterss reduction itself in the extension direction cannot produce buckling of the crust, and thus the wavelike detachment faults during extension (cf. Spencer, 1982).

If the extension in the $y$ direction is associated with a compression in the $x$ direction (i.e., $\sigma_{x x}>\sigma_{z z}>\sigma_{y y}$ or $\alpha>$ 1 and $\beta<1$ ), then the buckling condition represented in equation (12) may be satisfied. The relationship among the magnitude of $\sigma_{x x}$ as represented by the $\alpha$ value, the dominant half wavenumber $m$, and the thickness of the elastic crust $h$ is shown in Figure 4a. The half wavenumber $n$ is taken to be $n=1$ for the consideration of the minimum energy causing buckling (Timoshenko and Gere, 1961). The size of the plate is assumed to be $a=300 \mathrm{~km}$ and $b=60 \mathrm{~km}$, and $\beta=0.8$ is assumed. Figure $4 \mathrm{a}$ shows that a thinner elastic plate would be buckled with a shorter wavelength. It can be seen that all the curves have minima which are the minimum $\alpha$ to cause buckling. The dominant wavelengths at the initiation of buckling can be defined by the half wavenumbers corresponding to the minima. For the elastic plate with thickness $h$ varying from 2.5 to $7.5 \mathrm{~km}$, the initial dominant half wavenumber $m$ ranges from 7 to 10 (Figure $4 a$ ). This gives a dominant wavelength of 60.0-85.4 km for a 300$\mathrm{km}$-long extensional belt. If $a$ and $b$ remain the same and the magnitude of the compressive stress in the extension direction increases from $\beta=0.8$ to $\beta=0.2$, we find that the dominant wavelength decreases between 37.5 and $60 \mathrm{~km}$ (cf. Figures $4 a$ and $4 b$ ). The latter estimate corresponds well to the observed dominant wavelength of domes in the lower Colorado River region (Figure 1), implying that the effective elastic thickness of the crust is thin, probably less than 10 


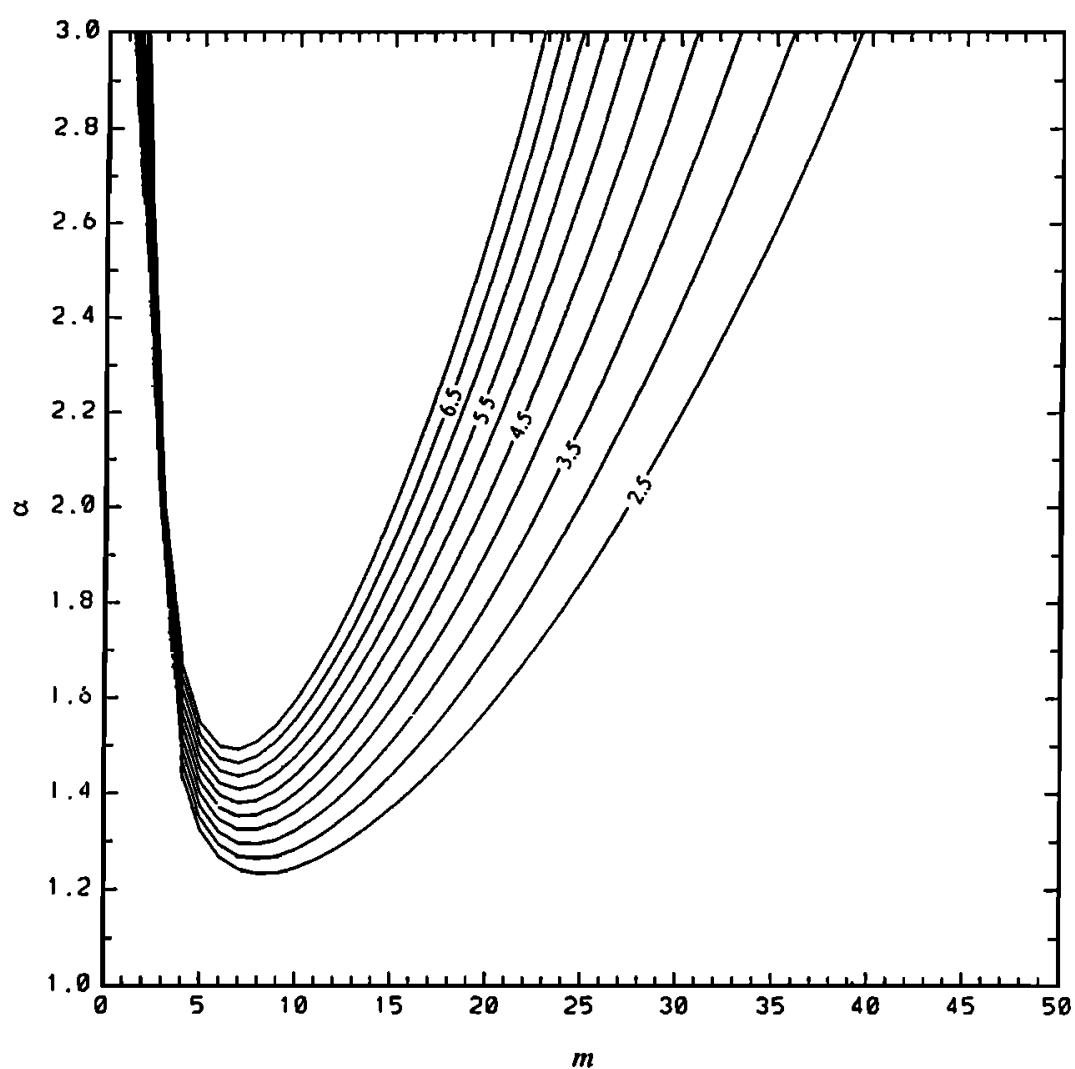

Fig. 4a. Relations among the magnitude of $\sigma_{x x}$ as represented by $\alpha$, the dominant half wavenumber $m$, and the thickness of the elastic crust $h$. $\beta$ assumed to be $0.8, a=300 \mathrm{~km}, b=60 \mathrm{~km}$, and $h$ ranging from 2.5 to $7.0 \mathrm{~km}$.

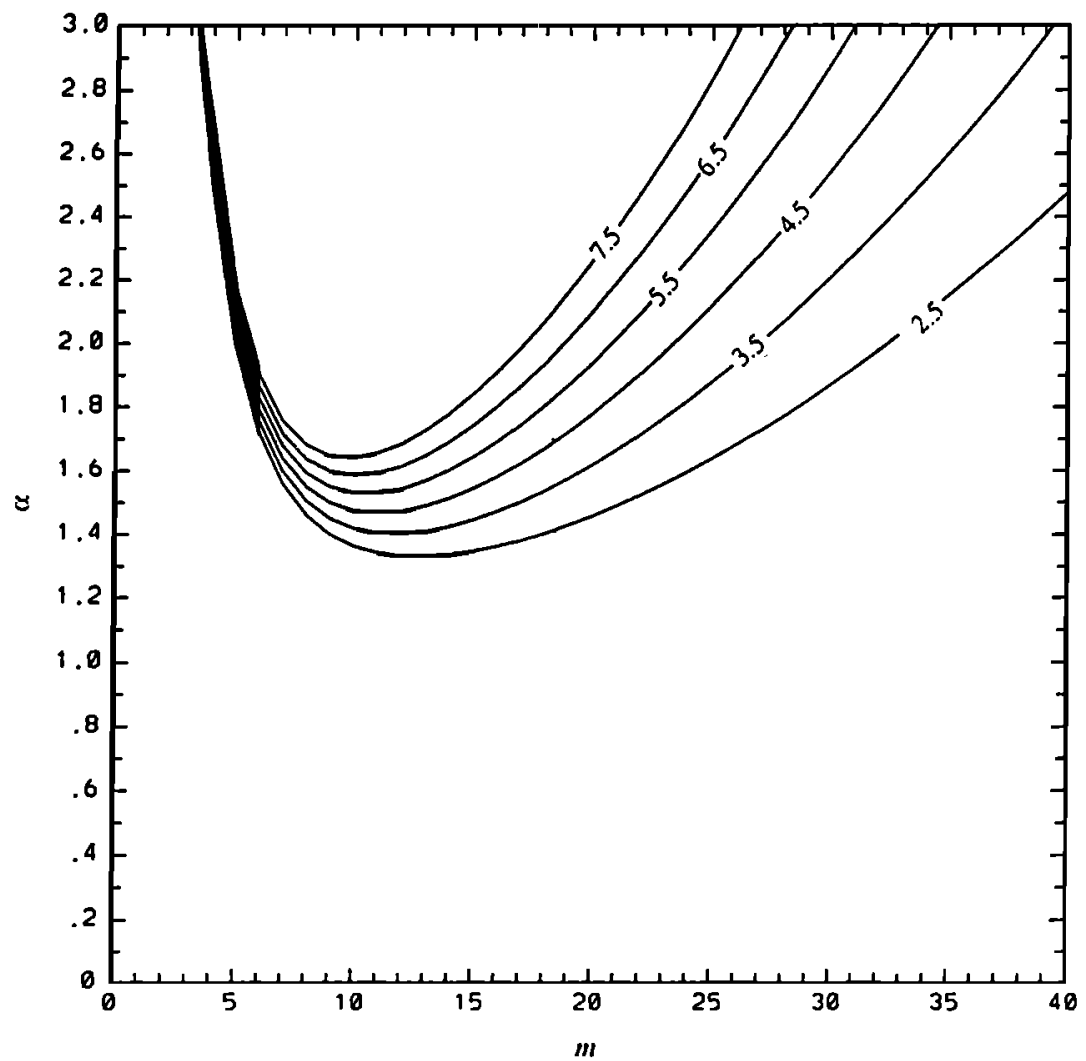

Fig. 4b. Relations among the magnitude of $\sigma_{x x}$ as represented by $\alpha$, the dominant half wavenumber $m$, and the thickness of the elastic crust $h$. $\beta$ assumed to be 0.2 (cf. Fig. $4 a$ ), $a=300 \mathrm{~km}, b=60 \mathrm{~km}$, and $h$ ranging from 2.5 to $7.5 \mathrm{~km}$. 
$\mathrm{km}$, during the extension and that the extensional deviatoric stress $\left(\sigma_{x x}-\sigma_{y y}\right)$ is relatively high.

If $\alpha=\beta=1$, then the state of stress is lithostatic. The effect of deviatoric stress on deflection of an elastic plate in this case is completely removed from equation (10b). The amplitude of deflection for this case is

$$
A_{m n}=\frac{4 \int_{0}^{a} \int_{0}^{b} q(x, y) \sin \left(\frac{m \pi x}{a}\right) \sin \left(\frac{n \pi y}{b}\right) d x d y}{a b D \pi^{4}\left(\frac{m^{2}}{a^{2}}+\frac{n^{2}}{b^{2}}\right)^{2}}
$$

It depends on the vertical load, the size of the plate, and the flexural rigidity of the plate.

\section{Deflection Due to Combined Vertical} and Horizontal Forces

Uniform loading. If the distribution of the vertical force $q(x, y)$ is uniform and is due to the uncompensated crustal root, we have

$$
q(x, y)=\left(\rho_{m}-\rho_{c}\right) g d_{0}
$$

where $d_{0}$ is the depth of the crustal root measured from the average depth of the Moho to the regional depth of isostatic compensation at which the density contrast is zero and $\rho_{m}$ and $\rho_{c}$ are the density of the mantle and the crust, respectively. Inserting (16) into $(10 \mathrm{~b})$, we have

$$
\begin{gathered}
A_{m n}=\left[16\left(\rho_{m}-\rho_{c}\right) g d_{0}\right] /\left\{a b D \pi ^ { 6 } \left[\left(\frac{m^{2}}{a^{2}}\right.\right.\right. \\
\left.\left.\left.+\frac{n^{2}}{b^{2}}\right)^{2}+\frac{6 \rho_{c} g\left(1-\nu^{2}\right)}{E h \pi^{2}}\left((1-\alpha) \frac{m^{2}}{a^{2}}+(1-\beta) \frac{n^{2}}{b^{2}}\right)\right]\right\}
\end{gathered}
$$

where $m$ and $n$ are odd numbers. Equation (17) shows that the deflection is a function of the depth of the crustal root $d_{0}$, the thickness of the elastic plate $h$, the size of the elastic plate $a$ and $b$, and the magnitude of the horizontal stresses represented by $\alpha$ and $\beta$. This geometry of a crustal root may find that the shape of the cross sections are approximately the same except at the ends of the plate near $x=0 \mathrm{~km}$ and $x=300 \mathrm{~km}$. This implies that a two-dimensional model is a good approximation for simulating deflection of a long plate with a uniform load. The maximum deflection in this case is about $49 \mathrm{~m}$. Figure $5 \mathrm{~b}$ shows the deflection pattern with the same parameters as used in Figure 5a except that the elastic thickness of the crust $h$ is reduced from 12 to $10 \mathrm{~km}$. We find that the maximum deflection is increased from 49 to $73 \mathrm{~m}$.

Sinusoidal vertical loading in the $x$ or $y$ directions. If the geometry of the crustal root is not uniform, it can be described in general by a double Fourier series. We now consider a simple case in which the crustal root is sinusoidal in either the $x$ or $y$ direction. The vertical load can be determined from (6) as

$$
q(x, y)=\frac{1}{2}\left(\rho_{m}-\rho_{c}\right) g\left[d_{0}-a_{r} \sin \left(\frac{j \pi x}{a}\right)\right]
$$

be appropriate for the case where there is little variation of the crustal root in depth beneath the extensional belt.

As shown in equation (17), $A_{m n}$ decreases as half wavenumbers $m$ and $n$ increase. With $A_{m n}$ so defined in (17), the series in equation (10a) converges very fast and the sign of the first term $A_{11} \sin (\pi x / a) \sin (\pi y / b)$ determines the sign of the series. Because

$$
q(x, y)=\left(\rho_{m}-\rho_{c}\right) g d_{0}>0
$$

the sign $w$ is completely dependent on the sign of the denominator in equation (17) which is the same expression as in equation (12).

Figure 5a shows the deflection pattern due to a stress reduction in the $y$ direction $(\beta=0.5)$ and a uniform vertical load induced by the presence of a crustal root $\left(d_{0}=20 \mathrm{~km}\right)$. The stress component in the $\boldsymbol{x}$ direction remains the same as the lithospheric stress (i.e., $\alpha=1.0$ ). The elastic thickness of the crust is taken to be $12 \mathrm{~km}$, and the length $a$ and width $b$ of the plate are taken to be $300 \mathrm{~km}$ and $60 \mathrm{~km}$, respectively. The deflection pattern is a broad upward warp. If we make cross sections parallel to the $y$ direction across the warp, we

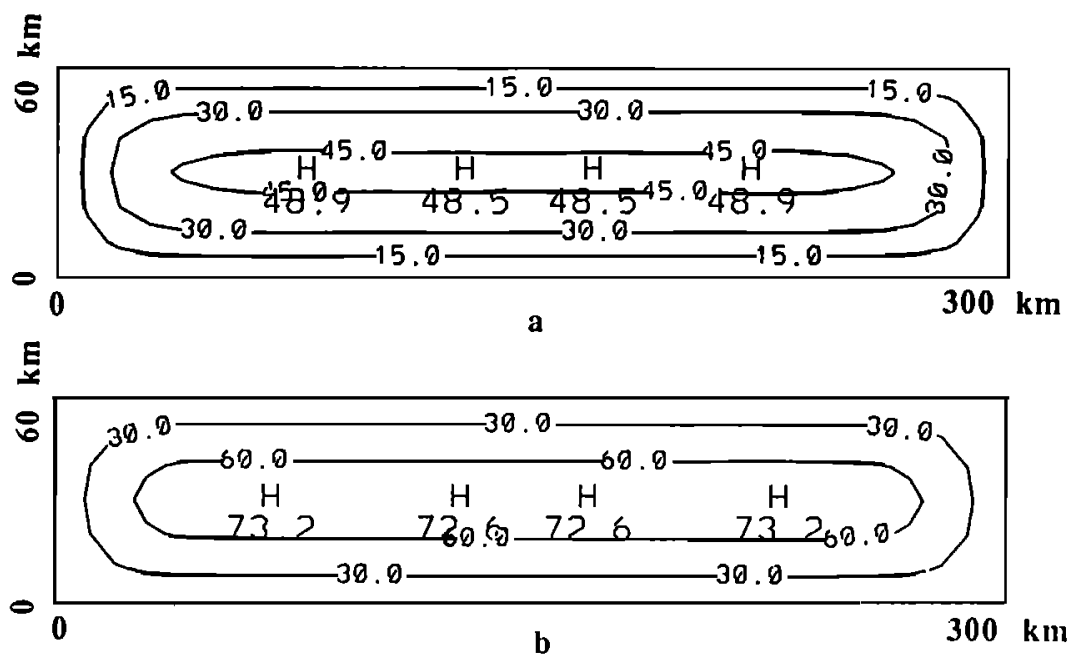

Fig. 5. a Deflection pattern due to a stress reduction in the $y$ direction for $a=300 \mathrm{~km}, b=60 \mathrm{~km}, h=12 \mathrm{~km}$, $d_{0}=20 \mathrm{~km}, \alpha=1.0$, and $\beta=0.5$. Solid lines for positive or upward deflection. Contour interval, $15 \mathrm{~m}$. $b$ Deflection pattern due to a stress reduction in the $y$ direction. All parameters are the same as those in Figure $5 \mathrm{a}$ except that $h$ is reduced from 12 to $10 \mathrm{~km}$. Contour interval, $30 \mathrm{~m}$. 
for a sinusoidal load in the $x$ direction with a half wavenumber equal to $j$, and as

$$
q(x, y)=\frac{1}{2}\left(\rho_{m}-\rho_{c}\right) g\left[d_{0}-a_{r} \sin \left(\frac{k \pi y}{b}\right)\right]
$$

for a sinusoidal load in the $y$ direction for a half wavenumber equal to $k ; d_{0}$ is the average length of the crustal root, and $a_{r}$ is the amplitude of the Moho topography. In the following calculation, I assume $d_{0}=a_{r}$ and $\dot{\alpha}=1.0$. Inserting (19) into (10b), we have

$$
\begin{gathered}
A_{m n}^{j}=\frac{2\left(\rho_{m}-\rho_{c}\right) g d_{0}}{n D \pi^{5}\left[\left(\frac{j^{2}}{a^{2}}+\frac{n^{2}}{b^{2}}\right)^{2}+\frac{6 \rho_{c} g\left(1-\nu^{2}\right)}{E h \pi^{2}}\left((1-\beta) \frac{n^{2}}{b^{2}}\right)\right]} \\
+\left\{\left[8\left(\rho_{m}-\rho_{c}\right) g d_{0}\right] /\left\{( 2 m - 1 ) ( 2 n - 1 ) D \pi ^ { 6 } \left[\left(\frac{(2 m-1)^{2}}{a^{2}}\right.\right.\right.\right. \\
\left.\left.\left.\left.+\frac{(2 n-1)^{2}}{b^{2}}\right)^{2}+\frac{6 \rho_{c} g\left(1-\nu^{2}\right)(1-\beta)(2 n-1)^{2}}{E h \pi^{2} b^{2}}\right]\right\}\right\}
\end{gathered}
$$

for a sinusoidal load in the $x$ direction, and

$$
\begin{gathered}
A_{m n}^{k}=\frac{2\left(\rho_{m}-\rho_{c}\right) g d_{0}}{n D \pi^{5}\left[\left(\frac{m^{2}}{a^{2}}+\frac{k^{2}}{b^{2}}\right)^{2}+\frac{6 \rho_{c} g\left(1-\nu^{2}\right)(1-\beta) k^{2}}{E h \pi^{2} b^{2}}\right]} \\
+\left\{\left[8\left(\rho_{m}-\rho_{c}\right) g d_{0}\right] /\left\{( 2 m - 1 ) ( 2 n - 1 ) D \pi ^ { 6 } \left[\left(\frac{(2 m-1)^{2}}{a^{2}}\right.\right.\right.\right. \\
\left.\left.\left.\left.+\frac{(2 n-1)^{2}}{b^{2}}\right)^{2}+\frac{6 \rho_{c} g\left(1-\nu^{2}\right)(1-\beta)(2 n-1)^{2}}{E h \pi^{2} b^{2}}\right]\right\}\right\}
\end{gathered}
$$

for a sinusoidal load in the $y$ direction. From (20a) and (20b) we obtain solutions for $w$

$$
\begin{gathered}
w=\sin \left(\frac{j \pi x}{a}\right) \\
\sum_{n=1}^{\infty} \frac{2\left(\rho_{m}-\rho_{c}\right) g d_{0}}{n D \pi^{5}\left[\left(\frac{i^{2}}{a^{2}}+\frac{n^{2}}{b^{2}}\right)^{2}+\frac{6 \rho_{c} g\left(1-\nu^{2}\right)(1-\beta) n^{2}}{E h \pi^{2} b^{2}}\right]} \sin \left(\frac{n \pi y}{b}\right)
\end{gathered}
$$

$$
\begin{gathered}
+\sum_{m=1}^{\infty} \sum_{n=1}^{\infty}\left\{\left[8\left(\rho_{m}-\rho_{c}\right) g d_{0}\right]\right. \\
/\left\{( 2 m - 1 ) ( 2 n - 1 ) D \pi ^ { 6 } \left[\left(\frac{(2 m-1)^{2}}{a^{2}}\right.\right.\right. \\
\left.\left.\left.\left.+\frac{(2 n-1)^{2}}{b^{2}}\right)^{2}+\frac{6 \rho_{c} g\left(1-\nu^{2}\right)(1-\beta)(2 n-1)^{2}}{E h \pi^{2} b^{2}}\right]\right\}\right\} \\
\sin \left(\frac{m \pi x}{a}\right) \sin \left(\frac{n \pi y}{b}\right)
\end{gathered}
$$

for a sinusoidal load in the $x$ direction and

$$
\begin{gathered}
w=\sin \left(\frac{k \pi y}{b}\right) \\
\sum_{m=1}^{\infty} \frac{2\left(\rho_{m}-\rho_{c}\right) g d_{0}}{n D \pi^{5}\left[\left(\frac{m^{2}}{a^{2}}+\frac{k^{2}}{b^{2}}\right)^{2}+\frac{6 \rho_{c} g\left(1-\nu^{2}\right)(1-\beta) k^{2}}{E h \pi^{2} b^{2}}\right]} \sin \left(\frac{m \pi x}{a}\right) \\
+\sum_{m=1}^{\infty} \sum_{n=1}^{\infty}\left\{\left[8\left(\rho_{m}-\rho_{c}\right) g d_{0}\right] /\right. \\
\left\{( 2 m - 1 ) ( 2 n - 1 ) D \pi ^ { 6 } \left[\left(\frac{(2 m-1)^{2}}{a^{2}}\right.\right.\right. \\
\left.\left.\left.\left.+\frac{(2 n-1)^{2}}{b^{2}}\right)^{2}+\frac{6 \rho_{c} g\left(1-\nu^{2}\right)(1-\beta)(2 n-1)^{2}}{E h \pi^{2} b^{2}}\right]\right\}\right\} \\
\sin \left(\frac{m \pi x}{a}\right) \sin \left(\frac{n \pi y}{b}\right)
\end{gathered}
$$

for a sinusoidal load in the $y$ direction. Note that the subscripts $n$ or $m$ are no longer variables in the first terms in equations (21a) and (21b) but are equal to $j$ and $k$, respectively. This relation shows how the shape of the uncompensated crustal root described by the half wave-numbers $j$ and $\boldsymbol{k}$ partially controls the deflection pattern.

Figure 6a shows the deflection pattern for a sinusoidal load with a half wavenumber of $j=15$ in the $x$ direction, $\beta=0.8$, $h=8 \mathrm{~km}, d_{0}=20 \mathrm{~km}, a=300 \mathrm{~km}$, and $b=60 \mathrm{~km}$. Because the load is not uniform, a two-dimensional model would not be
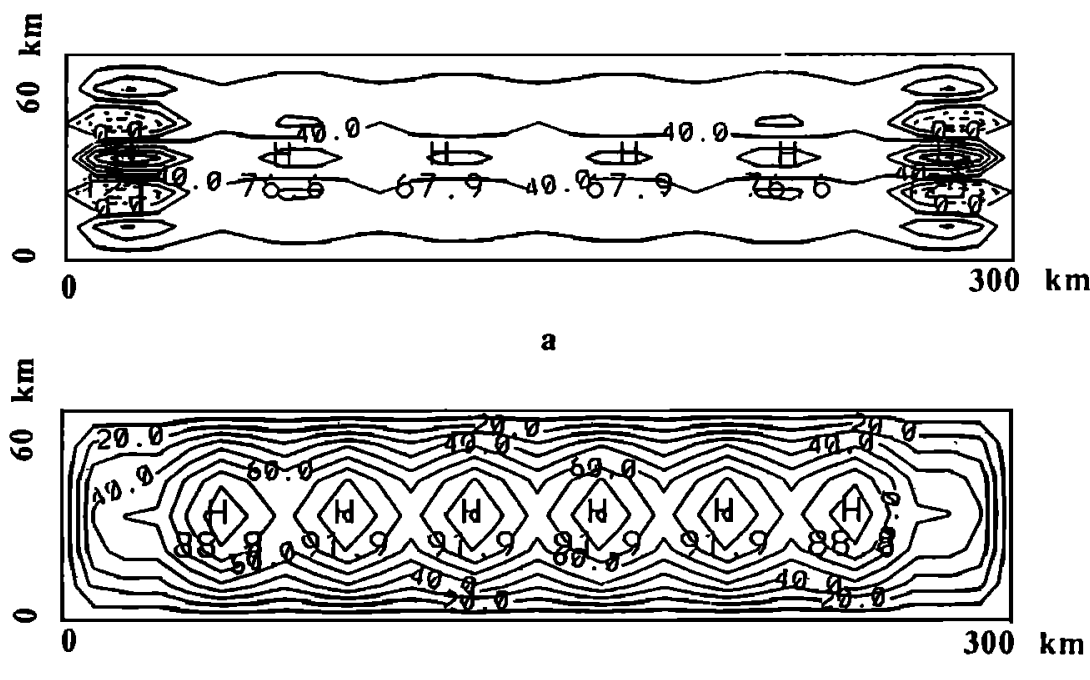

b

Fig. 6. a Deflection pattern due to a sinusoidal load in the $x$ direction for $a=300 \mathrm{~km}, b=60 \mathrm{~km}, \alpha=1.0, \beta=0.8$, $h=8 \mathrm{~km}$, and $d_{0}=20 \mathrm{~km}$. Contour interval, $10 \mathrm{~m}$. b Deflection pattern due to a sinusoidal load in the $y$ direction for $a=300 \mathrm{~km}, b=60 \mathrm{~km}, \alpha=1.0, \beta=0.8, h=8 \mathrm{~km}$, and $d_{0}=20 \mathrm{~km}$. Contour interval, $20 \mathrm{~m}$. 

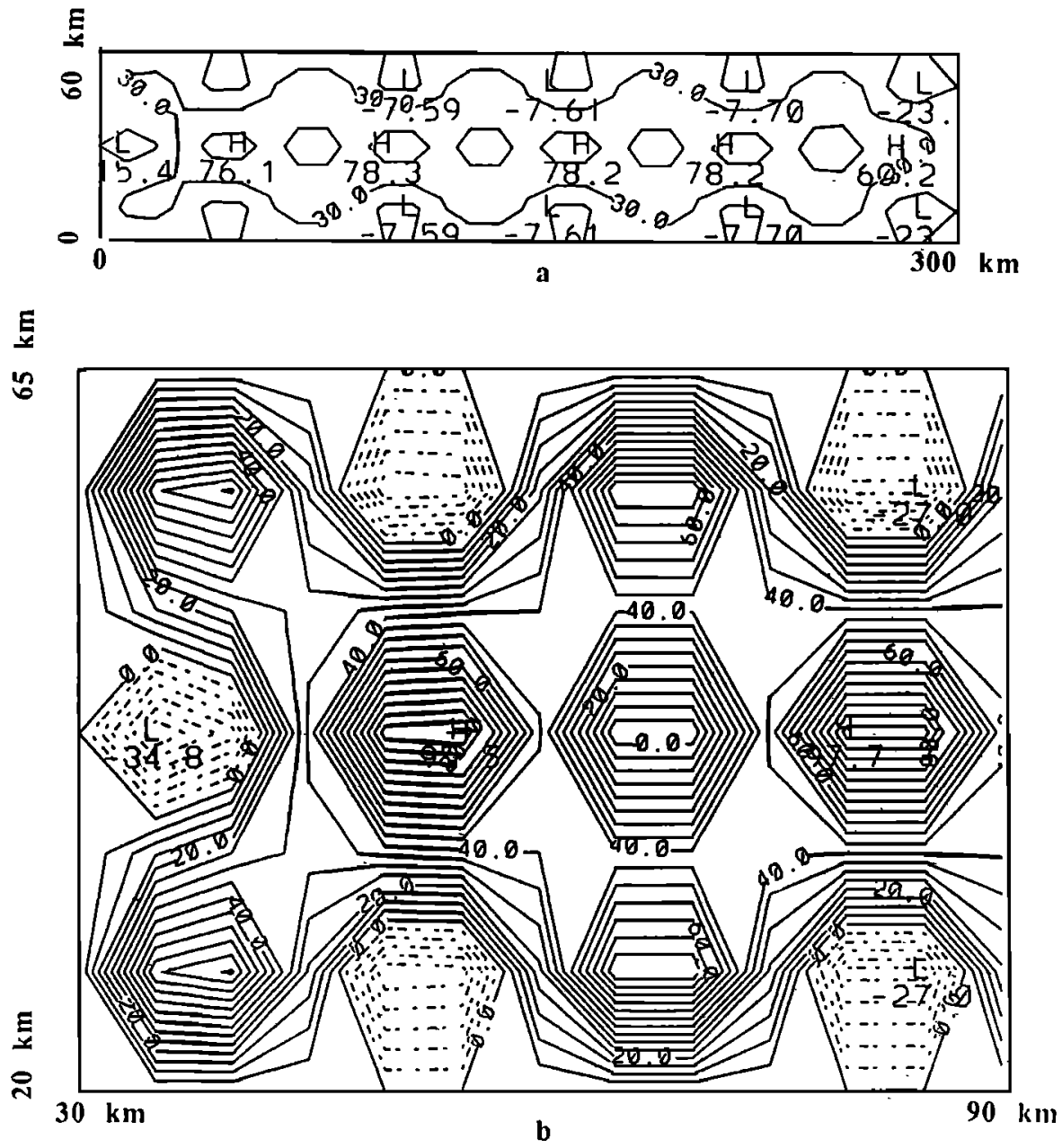

Fig. 7. a Deflection pattern due to a sinusoidal load in both the $x$ and $y$ directions for $a=300 \mathrm{~km}, b=60 \mathrm{~km}$, $\alpha=1.0, \beta=0.8, h=8 \mathrm{~km}$, and $d_{0}=20 \mathrm{~km}$. Contour interval, $30 \mathrm{~m}$. b Detailed deflection pattern of a portion of Figure 7a. Contour interval, $5 \mathrm{~m}$.

appropriate in this case for simulating the deflection of the plate. Figure 6a shows a periodic, wavelike pattern which is produced by the sinusoidal vertical load. A periodic distribution of plutons can produce a similar pattern, except that the magnitude of deflection would be different from that in Figure 6a.

Figure $6 \mathrm{~b}$ shows that the deflection pattern for a sinusoidal load with a half wavenumber of $k=5$ in the $y$ direction, $\beta=0.8, h=8 \mathrm{~km}, d_{0}=20 \mathrm{~km}, a=300 \mathrm{~km}$, and $b=60 \mathrm{~km}$. Such a loading condition produces narrow antiforms and synforms with their major axes parallel to the extensional belt.

Sinusoidal loading in both the $x$ and $y$ directions. If the distribution of the vertical force is sinusoidal in both the $x$ and $y$ directions, and again is due to the uncompensated crustal root, we have

$$
q(x, y)=\frac{1}{2}\left(\rho_{m}-\rho_{c}\right) g\left[d_{0}-a_{r} \sin \left(\frac{j \pi x}{a}\right) \sin \left(\frac{k \pi y}{b}\right)\right]
$$

where $d_{0}$ is the maximum depth of the crustal root. Inserting (22) into (10) and assuming $d_{0}=a_{r}$ and $\alpha=1$, we have

$$
w=\sum_{m=1}^{\infty} \sum_{n=1}^{\infty} A_{m n} \sin \left(\frac{m \pi x}{a}\right) \sin \left(\frac{n \pi y}{b}\right)
$$

where

$$
\begin{gathered}
A_{m n}=\frac{1}{2} \frac{\left(\rho_{m}-\rho_{c}\right) g d_{0}}{D \pi^{4}\left[\left(\frac{j^{2}}{a^{2}}+\frac{k^{2}}{b^{2}}\right)^{2}+\frac{6 \rho_{c} g\left(1-\nu^{2}\right)}{E h \pi^{2}}\left((1-\beta) \frac{k^{2}}{b^{2}}\right)\right]} \\
+\left\{\left[8\left(\rho_{m}-\rho_{c}\right) g d_{0}\right] /\left\{( 2 m - 1 ) ( 2 n - 1 ) D \pi ^ { 6 } \left[\left(\frac{(2 m-1)^{2}}{a^{2}}\right.\right.\right.\right. \\
\left.\left.\left.\left.+\frac{(2 n-1)^{2}}{b^{2}}\right)^{2}+\frac{6 \rho_{c} g\left(1-\nu^{2}\right)}{E h \pi^{2}}(1-\beta) \frac{(2 n-1)^{2}}{b^{2}}\right]\right\}\right\}
\end{gathered}
$$

The first term in equation (23b) shows again how the geometry of the crustal root described by half wavenumbers $j$ and $k$ influences the solution.

Figure $7 \mathrm{a}$ shows the deflection pattern for $j=10, k=3$, $\beta=0.8, h=10 \mathrm{~km}, d_{0}=20 \mathrm{~km}, a=300 \mathrm{~km}$, and $b=60 \mathrm{~km}$. A number of structural domes and basins are produced by the assumed vertical load. The pattern of deflection mimics the assumed geometry of the crustal root. A portion of the deflection pattern is shown in detail in Figure $7 \mathrm{~b}$ which covers the region for $x$ between 30 and $90 \mathrm{~km}$ and $y$ between 20 and $65 \mathrm{~km}$. These figures imply that if the bounyant force is periodically distributed, then the crust can be warped in a wavelike pattern. As plutons are commonly spaced evenly during their emplacement (e.g., Ramberg, 1981, p. 250253), it is possible that the formation of regulerly spaced, domal and basinal detachment faults is related to pluton emplacement. 


\section{Deflection Due to Basal Shearing}

One possible factor, the basal shearing tractions acting on the base of the elastic plate, was ignored in the previous analyses. This shearing traction may have played an important role during the evolution of the core complexes and related detachment faults [Yin, 1989a]. The shearing may have resulted from spreading of the overthickened lower crust formed during the Sevier and Laramide orogenies triggered by Tertiary magmatism [Coney and Harms, 1984]. The crustal thickening in the North American Cordillera during Mesozoic time may be of the Andean type and may have been accomplished by either magmatic addition, tectonic shortening, or the combination of both [Allmendinger, 1986]. Shearing at the base of the brittle upper crust due to spreading of magma has also been suggested as a cause for the development of the detachment fault systems in the Eldorado Mountains, southeastern Nevada [Anderson, 1971].

If a shearing traction exists at the base of the upper crust, the lower crust cannot be approximated as an inviscid fluid, and the effect of viscous drag must be considered in the boundary conditions along the bottom and edges of the plate. The viscosity of the lower crust is strongly dependent on the thermal gradient [e.g., Sibson, 1982; Chen and Molnar, 1983]. If the thermal gradient is high, then the viscous resistance is low. In this case, the viscous effect on the plate boundaries may be neglected. In contrast, if the thermal gradient is low, then the viscous resistance is high, and the effect of the viscosity cannot be ignored. Thus the boundary conditions along the edges of the extensional belt should be justified by geologic constraints.

Cordilleran core complexes occur in a narrow belt ranging in width from a few tens of kilometers to about $150 \mathrm{~km}$ [Coney, 1980]. This belt developed diachronously, younging in general from north to south. In a broad sense, the development of the core complexes was spatially and temporally associated with igneous activity [e.g., Gans, 1987; Gans et al., 1989; Armstrong, 1982]. The exact causal relationship between extension and plutonism, however, remains controversial. On the basis of these geologic conditions, I consider that the viscous effect on the edges of the extensional belt that bound its long dimension can be ignored. Along the sides of the extensional belt that bound its short dimension, I assume that the deflection is zero.
If we assume the basal shear is uniform and acting in the $y$ direction, then equation (1) can be written as

$$
\begin{gathered}
\frac{\partial^{4} w}{\partial x^{4}}+2 \frac{\partial^{4} w}{\partial x^{2} \partial y^{2}}+\frac{\partial^{4} w}{\partial y^{4}}=\frac{1}{D}\left[q(x, y)+N_{x}(x, y) \frac{\partial^{2} w}{\partial x^{2}}\right. \\
\left.+N_{y}(x, y) \frac{\partial^{2} w}{\partial y^{2}}+\sigma_{z y}(-h / 2) \frac{\partial w}{\partial y}\right]
\end{gathered}
$$

where $q(x, y)$ is the vertical load due to buoyancy as defined previously, and $\sigma_{z y}$ is the shear traction acting at the base of the plate in the $y$ direction. The analytical solution can be obtained as (Appendix B)

$$
w=\sum_{m=1}^{\infty} f(y) \sin \left(\frac{m \pi x}{a}\right)
$$

where

$$
\begin{gathered}
f(y)=e^{a_{1} y}\left[C_{1} \cos \left(b_{1} y\right)+C_{2} \sin \left(b_{1} y\right)\right] \\
+e^{a_{2} y}\left[C_{3} \cos \left(b_{2} y\right)+C_{4} \sin \left(b_{2} y\right)\right] \\
+\frac{q}{D\left(\frac{m^{4} \pi^{4}}{a^{4}}+\frac{N_{x} m^{2} \pi^{2}}{D a^{2}}\right)}
\end{gathered}
$$

$C_{1}, C_{2}, C_{3}$, and $C_{4}$ are constants to be determined by the boundary conditions.

Figure 8 shows the deflection pattern for a basal shear stress equal to $1 \mathrm{MPa}$. The size of the plate is assumed to be $150 \mathrm{~km}$ long and $60 \mathrm{~km}$ wide. Other parameters are $\alpha=1, \beta=0.8, h=10 \mathrm{~km}$, and $d_{0}=4 \mathrm{~km}$. By trying different model parameters, I found that the amplitude of deflection due to the basal shearing is very sensitive to the size of the extensional belt if the crustal thickness helds constant. For example, if a plate is $10-\mathrm{km}$ thick, $300-\mathrm{km}$ long, and $60-\mathrm{km}$ wide, then the maximum amplitude is about $11 \mathrm{~km}$ for a $1 \mathrm{MPa}$ basal shear, far beyond the limit of the elastic thin plate theory. This result implies that the basal shearing can also result in buckling, although the buckling condition cannot be explicitly expressed.

\section{Discussion}

The results of the aforementioned analyses suggest two possible mechanisms to explain the formation of the domal

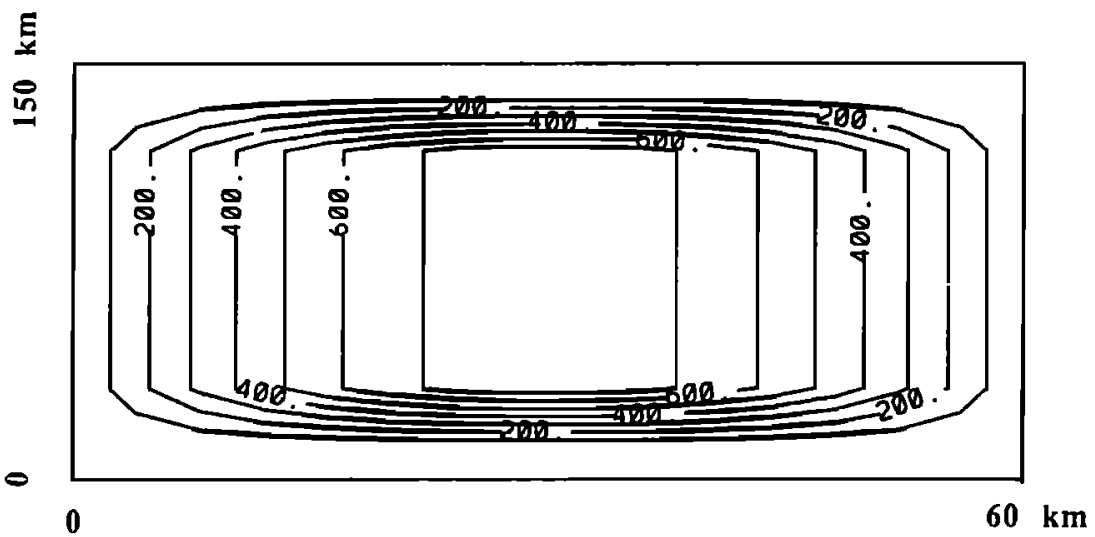

Fig. 8. Deflection pattern due to combined vertical, horizontal, and basal shearing forces. Basal shear stress equals to $1 \mathrm{MPa}, \alpha=1.0, \beta=0.8, h=12 \mathrm{~km}, a=300 \mathrm{~km}$, and $b=60 \mathrm{~km}$. Crustal root assumed to be uniform and is emplaced $4 \mathrm{~km}$ deep into the mantle, i.e., $d_{0}=4 \mathrm{~km}$. 
and basinal detachment faults: (1) the presence of uncompensated crustal roots with irregular geometries or buoyant synextensional plutons beneath core complexes, and (2) buckling due to a compression in the direction perpendicular to the extension direction particularly during the later stage of detachment faulting when the thickness of the elasticbrittle upper crust was so thin that a slight compression perpendicular to the extension direction could cause buckling (Figure 4). Both mechanisms are geologically likely based on the timing of regional igneous and tectonic activity during the middle Tertiary in the North American Cordillera. First, the core complexes are located in areas where the crust was significantly thickened during Mesozoic time, and the occurrence of core complex extension was broadly synchronous with middle Tertiary igneous activity. Both conditions could provide the source of buoyant forces for the formation of domes, particularly during the later stage of core complex development when the thickness of the brittle-elastic upper crust in an extensional belt was reduced significantly by both detachment faulting and thermal heating.

The inferred compression perpendicular to the extension direction is consistent with the geologic constraints on timing and structural styles during the middle Miocene in the lower Colorado River region around the triple junction of Nevada, Arizona, and California. The northern boundary of the Colorado River Extensional Corridor and its northern extension in the Eldorado Mountains, Nevada, is marked by systems of strike-slip faults that trend both in the northeast and northwest directions. The most well-known faults in this region are the Lake Mead fault system and the Las Vegas shear zone. The two fault systems have displacements of several tens of kilometers and represent a generally N-S compression that is subperpendicular to the extension direction in the areas to the south. The main phase of movement along the two strike-slip fault systems is between 17 and $6 \mathrm{Ma}$ [Bohannon, 1984], overlapping the late stage of extension associated with low-angle normal faults and detachment faulting in the Eldorado Mountains, Nevada, between 15 and $11 \mathrm{Ma}$ [Anderson, 1971] and the Colorado River Extensional Corridor area between 23 and $14 \mathrm{Ma}$ [Nielson and Beratan, 1990]. The main phase of domal uplifts in the region was indicated by the widespread occurrence of monolithologic breccias and landslide complexes that postdate the $18 \mathrm{Ma}$ Peach Spring Tuff [Nielson and Beratan, 1990; A. Yin and J.F. Dunn, Manuscript in review, Geological Society of American Bulletin, 1991]. Thus, doming in the Colorado River Extensional Corridor was coeval with strike-slip faulting to the north.

As noted by Holt et al. [1986], some of the Cordilleran core complexes have higher elevations than the adjacent less extended areas. They proposed that the development of later Basin and Range high-angle faults in conjunction with the presence of uncompensated crustal roots are the driving mechanism for the uplift of core complexes. The results of this study show that at least three mechanisms can lift an extended area: (1) buckling due to a compression perpendicular to the extension direction, (2) buoyant forces due to the presence of uncompensated crustal roots or synextensional plutons, and (3) the existence of a basal shearing traction at the base of the upper crust. The second mechanism for the uplift of an extended area above the adjacent unextended area is similar to Holt et al.'s [1986] interpretations. The final elevation of an extended area is the balance between the magnitude of upward deflection due to the three mechanisms listed above and the amount of extension that lowers the elevation of an extended region.

The analytical solutions obtained here provide a means to examine the interactions among different physical factors that may have controlled the warping of detachment faults. However, these solutions are based on extremely simplified assumptions that may not accurately approximate geologic reality. The following improvements of the model are needed in future studies:

1. More realistic, irregular geometry of an extensional belt should be used to evaluate its effect on the detailed warping pattern of detachment faults.

2. The elastic thickness of the upper crust could be allowed to vary, so that the flexural rigidity $D$ is a function of spatial position.

3. The isostatic restoring force during extension also affects the deflection and should be considered. This force is a function of the magnitude and distribution of extension in the extensional belt, as modeled by Spencer [1984] and Weissel and Karner [1989].

4. Because the model applies elastostatic theory, the results obtained here represent either the condition for the onset of buckling or an instantaneous loading condition. The observed geologic structures, such as the geometry of warped detachment faults, may be a result of the superimposition of many events of deflection through time induced by stress reduction, upward pushing due to buoyancy forces, and compression perpendicular to the extension direction. Consideration of the superimposition of deflection in conjunction with the isostatic restoring force as a function of both time and space (which are fairly well constrained in many core complexes) would eventually help us to establish an evolutionary model for the development of detachment fault systems in three dimensions.

\section{Conclusion}

A three-dimensional model was developed in this study to explore the interactions among the vertical, horizontal, and basal shearing forces during the formation of warped detachment faults. The model considers the role of compression perpendicular to the extension direction and stress reduction parallel to the extension direction. The results of the model suggest that deflection of an elastic upper crust depends strongly on the state of horizontal stress components. The stress reduction itself in the extension direction is incapable of causing buckling of a thin elastic crust.

Two mechanisms have been identified that explain the formation of domal and basinal geometries of detachment faults: (1) an upward pushing by undulatory crustal roots or buoyant synextensional plutons beneath the extensional belt, and (2) buckling caused by compression perpendicular to the extension direction. Both mechanisms are consistent with the geologic constraints in different parts of the North American Cordillera during the development of core complexes. In addition to isostatic uplift due to tectonic denudation, upward warping of detachment faults can be caused by buckling, basal shearing, and buoyant forces induced by uncompensated crustal roots or synextensional plutons. 
Appendix A: Solution of Deflection For Combined Vertical and Horizontal Forces

Equation (1) can be solved by the potential energy method. In the case of a rectangular plate with simply supported edges, the deflection surface can be represented by a double Fourier series [Timoshenko and Gere, 1961; Timoshenko and Woinowsky-Krieger, 1959]

$$
w=\sum_{m=1}^{\infty} \sum_{n=1}^{\infty} A_{m n} \sin \left(\frac{m \pi x}{a}\right) \sin \left(\frac{n \pi y}{b}\right)
$$

Each term of this series vanishes for $x=0, x=a$ and also for $y=0, y=b$. Hence the deflection $w$ is zero along the boundary as required. Calculating the derivatives $\partial^{2} w / \partial x^{2}$ and $\partial^{2} w / \partial y^{2}$, we find again that each term of the calculated series is zero at the boundary. Thus (A1) satisfies the boundary conditions. The energy of bending is

$$
\Delta U=\frac{a b \pi^{4}}{8} D \sum_{m=1}^{\infty} \sum_{n=1}^{\infty} A_{m n}^{2}\left(\frac{m^{2}}{a^{2}}+\frac{n^{2}}{b^{2}}\right)^{2}
$$

Applying the principle of virtual displacements, we obtain

$$
A_{m n}=\frac{4 \int_{0}^{a} \int_{0}^{b} q(x, y) \sin \left(\frac{m \pi x}{a}\right) \sin \left(\frac{n \pi y}{b}\right) d x d y}{a b D \pi^{4}\left[\left(\frac{m^{2}}{a^{2}}+\frac{n^{2}}{b^{2}}\right)^{2}+\frac{1}{D \pi^{2}}\left(N_{x} \frac{m^{2}}{a^{2}}+N_{y} \frac{n^{2}}{b^{2}}\right)\right]}
$$

Replacing $N_{x}$ and $N_{y}$ by

$$
\begin{aligned}
& N_{x}=\frac{1}{2}(1-\alpha) \rho_{c} g h^{2} \\
& N_{y}=\frac{1}{2}(1-\beta) \rho_{c} g h^{2}
\end{aligned}
$$

we have

$$
\begin{gathered}
A_{m n}=\left[4 \int_{0}^{a} \int_{0}^{b} q(x, y) \sin \left(\frac{m \pi x}{a}\right)\right. \\
\left.\sin \left(\frac{n \pi \eta}{b}\right) d x d y\right] /\left\{a b D \pi ^ { 4 } \left[\left(\frac{m^{2}}{a^{2}}+\frac{n^{2}}{b^{2}}\right)^{2}\right.\right. \\
\left.\left.+\frac{6 \rho_{c} g\left(1-\nu^{2}\right)}{E h \pi^{2}}\left((1-\alpha) \frac{m^{2}}{a^{2}}+(1-\beta) \frac{n^{2}}{b^{2}}\right)\right]\right\}
\end{gathered}
$$

which is identical to $(10 b)$.

ApPendix B: Deflection for Combined Vertical, Horizontal, and Basal Shearing Forces

On the basis of geologic constraints during the development of Cordilleran core complexes, the following boundary conditions are assumed: a simply supported boundary condition along the edges of the plate at $x=0$ and $x=a$; and a zero-deflection condition along the edges at $y=0$ and $y=b$. Thus we have

$$
\begin{gathered}
(w)_{y=0, b}=\left(\frac{\partial w}{\partial x}\right)_{y=0, b}=0 \\
(w)_{x=0, a}=0 \\
\left(\frac{\partial^{2} w}{\partial x^{2}}+\nu \frac{\partial^{2} w}{\partial y^{2}}\right)_{x=0, a}=0
\end{gathered}
$$

Assuming that the plate buckles in $m$ sinusoidal halfwaves in the $x$ direction, we take the solution of equation (24) in the form

$$
w=\sum_{m=1}^{\infty} f(y) \sin \left(\frac{m \pi x}{a}\right)
$$

Substituting (B2) into (B1), we obtain an ordinary differential equation

$$
\frac{d^{4} f}{d y^{4}}+b_{0} \frac{d^{2} f}{d y^{2}}+c_{0} \frac{d f}{d y}+d_{o} f=\frac{q}{D}
$$

where

$$
\begin{gathered}
b_{0}=-\frac{m^{2} \pi^{2}}{a^{2}}+\frac{N_{y}}{D} \\
c_{0}=\frac{\sigma_{z y}}{D} \\
d_{0}=\frac{m^{4} \pi^{4}}{a^{4}}+\frac{N_{x} m^{2} \pi^{2}}{D a^{2}}
\end{gathered}
$$

Equations (B4a), (B4b), and (B4c) show the physical meaning of coefficients $b_{0}, c_{0}$, and $d_{0}: b_{0}$ is related to the length of the plate and horizontal force $N_{y}$ in the $y$ direction, $c_{0}$ is related to the basal shearing traction $\sigma_{z y}$, and $d_{0}$ is related to the length of the plate and the horizontal force $N_{x}$ in the $x$ direction.

The particular solution of (B3) is

$$
f^{*}(y)=\frac{q}{D d_{0}}
$$

We need to solve the following characteristic equation

$$
\lambda^{4}+b_{0} \lambda^{2}+c_{0} \lambda+d_{0}=0
$$

to determine the complementary solution of (B3). There are two pairs of conjugate complex roots for equation (B6)

$$
\begin{aligned}
& \lambda_{1,2}=a_{1} \pm i b_{1} \\
& \lambda_{1,2}=a_{2} \pm i b_{2}
\end{aligned}
$$

for the range of parameters used in this study. The roots are solved numerically by Laguerre's method. Once the roots of (B6) are found, we can express the complementary solution in the following form:

$$
\begin{gathered}
f_{1}(y)=e^{a_{1} y}\left[C_{1} \cos \left(b_{1} y\right)+C_{2} \sin \left(b_{1} y\right)\right] \\
+e^{a_{2} y}\left[C_{3} \cos \left(b_{2} y\right)+C_{4} \sin \left(b_{2} y\right)\right]
\end{gathered}
$$

$C_{1}, C_{2}, C_{3}$, and $C_{4}$ are constants to be determined by the boundary conditions along edges of the plate. Using the boundary conditions stated in equation (B1), we have

$$
\begin{gathered}
C_{1}+C_{3}=-\frac{q}{D d_{0}} \\
C_{1} e^{a_{1} b} \cos \left(b_{1} b\right)+C_{2} e^{a_{1} b} \sin \left(b_{1} b\right)+C_{3} e^{a_{2} b} \cos \left(b_{2} y\right) \\
+C_{4} e^{a_{2} b} \sin \left(b_{2} b\right)=-\frac{q}{D d_{0}}
\end{gathered}
$$

Constants $C_{2}$ and $C_{3}$ are set zero to yield the solutions finite for a large value $b$, which is of the order of a few tens of kilometers. The final solution of equation (24) is

$$
w=\sum_{m=1}^{\infty} f(y) \sin \left(\frac{m \pi x}{a}\right)
$$


where

$$
f(y)=e^{a_{1} y} C_{1} \cos \left(b_{1} y\right)+e^{a_{2} y} C_{4} \sin \left(b_{2} y\right)+\frac{q}{D d_{0}}(B 10 b)
$$

$C_{1}$ and $C_{4}$ are determined by (B9).

Acknowledgments. This work was supported by the Academic Senate Research Fund of the Unjversity of California, Los Angeles. Reviews by P. Bird, C. Chase, J. Christie, D. Diamond, D. Kemp, B. Hacker, G. Oertel, D. Young, and an anonymous JGR reviewer improved the original manuscript and are greatly appreciated. I thank Peter Bird for suggesting the transform used in equation (3).

\section{REFERENCES}

Allmendinger, R. W., Tectonic development, southeastern border of the Puna Plateau, northwestern Argentine Andes, Geol. Soc. Am. Bull., 97, 1070-1082, 1986.

Allmendinger, R. W., J.W. Sharp, D. Von Tish, L. Serpa, L. Brown, S. Kaufman, and J. Oliver, Cenozoic and Mesozoic structure of the eastern Basin and Range from COCORP seismic reflection data, Geology, 11, 532-536, 1983.

Anderson, E.R., Thin skin distension in Tertiary rocks of southeastern Nevada, Geol. Soc. Am. Bull., 82, 43-58, 1971.

Armstrong, R.L., Cordilleran metamorphic core complexes from Arizona to southem Canada, Annu. Rev. Earth Planet. Sci., 10, 129-154, 1982.

Block, L., and L. Royden, Core complex geometry and regional scale flow in the lower crust, Tectonics, 9, 557-567, 1990.

Bohannon, R.G., Nonmarine sedimentatary rocks of Tertiary age in the Lake Meade region, southeastern Nevada and northwestern Arizona, U.S. Geol. Surv. Prof. Pap. 1259, 1-69, 1984.

Buck, R., Flexural rotation of normal faults, Tectonics, 7, 959973, 1988.

Burchfiel, B.C., K.V. Hodges, and L.H. Royden, Geology of Panamint Valley-Saline Valley pull-apart system, California: Palinspastic evidence for low-angle geometry of a Neogene range-bounding fault, $J$. Geophys. Res., 92, 10,422-10,426, 1989.

Chen, W.P., and P. Molnar, Focal depth of intracontinental and intraplate earthquakes and their implications for the thermal and mechanical properties of the lithosphere, J. Geophys. Res., 88, 4183-4214, 1983.

Coney, P.J., Cordilleran metamorphic core complexes: An overview, in Cordilleran Core Complexes, edited by M.L. Crittenden, Jr., P.J. Coney, and G.H. Davis, Mem. Geol. Soc. Am. $153,7-34,1980$.

Coney, P.J., The regional tectonic setting and possible causes of Cenozoic extension in the North American Cordillera, in Continental Extensional Tectonics, edited by M.P. Coward, J.F. Dewey, and P.L. Hancock, Geol. Soc. Spec. Publ. London 28, 177-186, 1987.

Coney, P.J., and T.W. Harms, Cordilleran metamorphic core complexes: Cenozoic extensional relics of Mesozoic compression, Geology, 12, 550-554, 1984.

Crittenden, M.D., Jr., P.J. Coney, and G.H. Davis (Eds.), Cordilleran Core Complexes, Mem. Geol. Soc. Am. 153, 409 pp., 1980.

Davis, G.A., Rapid upward transport of mid-crustal mylonitic gneisses in the footwall of a Miocene detachment fault, Whipple Mountains, southeastern California, Geol. Rundsch., 77, 191209, 1988.

Davis, G.A., and G.S. Lister, Detachment faulting in continental extension: Perspective from the southwestern U.S. Cordillera, Spec. Pap. Geol. Soc. Am. 218, 133-159, 1988.

Davis, G.A., J.L. Anderson, E.G. Frost, and T.J. Shackelford, Mylonitization and detachment faulting in the Whipple-Buckskin-Rawhide Mountains terrane, southeastern California and western Arizona, in Cordilleran Core Complexes, edited by M.D. Crittenden, Jr., P.J. Coney, and G.H. Davis, Mem. Geol. Soc. Am. 153, 79-129, 1980.

Davis, G.A., J.L. Anderson, D. L. Martin, D. Krummenacher, and E. Front, Geologic and geochronologic relations in the lower plate of the Whipple Mountains detachment fault, Whipple Mountains, southeastern California: A progress report, in Mesozoic-Cenozoic tectonic evolution of the Colorado River Region, California, Arizona, and Nevada, edited by E.G. Frost and D.L. Martin, pp. 409-432, Cordilleran Publishers, San Diego, Calif., 1982.

Davis, G.A., G.S. Lister, and S.J. Reynolds, Structural evolution of the Whipple and South Mountains shear zones, southwestern United States, Geology, 14, 7-10, 1986.

Dickey, D.D., W.J. Carr, and W.B. Bull, Geologic map of the Parker NW, and parts of The Whipple Mountains SW and Whipple Wash quadrangles, California and Arizona, U.S. Geol. Surv. Misc. Invest. Ser. Map, I-1124, 1980.

Dickinson, W.R., Plate tectonic evolution of the southern Cordillera, in Relations of Tectonics to Ore Deposits in the Southern Cordillera, edited by W.R. Dickinson, and W.D. Payne, Ariz. Geol. Soc. Dig., 14, 113-135, 1981.

Doser, D.I., The Ancash, Peru earthquake of 1964 November 10: Evidence for low-angle normal faulting in the high Andes of northern Peru, Geophys. J. R. Astron. Soc., 91, 57-71, 1987.

Fletcher, R.C., Analysis of the flow in layered fluids at a small, but finite, amplitude with application to mullion structures, Tectonophysics, 33, T7-T15, 1982.

Frost, E.G., and D.L. Martin (Eds.), Mesozoic-Cenozoic Tectonic Evolution of the Colorado River Region, California, Arizona, and Nevada, Cordilleran Publishers, 608 pp., San Diego, Calif., 1982.

Fung, Y.C., Foundations of Solid Mechanics, 593 pp., Chapman and Hall, London, 1965.

Gans, P.B., An open system, two-layer crustal stretching model for the eastern Great Basin, Tectonics, 6, 1-12, 1987.

Gans, P.B., G.A. Mahood, and E. Schermer, Synextensional magmatism in the Basin and Range Province: A case study from the eastern Great Basin, Geol. Soc. Am. Spec. Pap. 233, $1-53,1989$.

Hamilton, W., Extensional faulting in the Death Valley region, Geol. Soc. Am. Abstr. Programs, 20, 165-166, 1988.

Hobbs, B.E., W.D. Means, and P.F. Williams, An Outline of Structural Geology, John Wiley, New York, 1976.

Holt, W. E., C. G. Chase, and T.C. Wallace, Crustal structure from three dimensional gravity modeling of of a metamorphic core complex: a model for uplift, Santa Catalina-Rincon Mountains, Arizona, Geology, 14, 827-930, 1986.

Howard, K.A., and B.E. John, Crustal extension along a rooted system of imbricate low-angle normal faults: Colorado River extensional corridor, California and Arizona, in Continental Extensional Tectonics, edited by M.P. Coward, J.F. Dewey, and P.L. Hancock, eds., Geol. Soc. Spec. Publ. London 28, 299-312, 1987.

Howard, K.A., J. W. Goodge, and B.E. John, Detached crystalline rocks of the Mohave, Buck, and Bill Williams Mountains, in Mesozoic-Cenozoic Tectonic Evolution of the Colorado River Region, California, Arizona, and Nevada, edited by E. G. Frost and D.L. Martin, pp. 377-392, Cordilleran Publishers, San Diego, Calif., 1982.

Hyndman, D.W., Bitterroot dome-Sapphire tectonic block, an example of a plutonic-core gneiss-dome complex with its detached superstructure, in Cordilleran Metamorphic Core Complexes, edited by M.D. Crittenden, Jr., P.J. Coney, and G.H. Davis: Mem Geol. Soc. Am. 153,427-443, 1980.

Jackson, J.A., and D.P. McKenzie, The geometrical evolution of normal fault systems, J. Struct. Geol., 5, 471-482, 1983.

Jackson, J.A., Active normal faulting and crustal extension, in Continental Extensional Tectonics, edited by M.P. Coward, J.F. Dewey, and P.L. Hancock, Geol. Soc. , Spec. Publ. London 28, 3-17, 1987.

Jackson, J.A., and N.J. White, Normal faulting in the upper continental crust: Observations from regions of active extension, J. Struct. Geol., 11, 15-36, 1989.

John, B.E., Geologic framework of the Chemehuevi Mountains area, southeastern California, in Mesozoic-Cenozoic Tectonic Evolution of the Colorado River Region, California, Arizona, and Nevada, edited by E.G. Frost and D.L. Martin, Pp. 317325, Cordilleran Publishers, San Diego, Calif., 1982.

John, B.E., Geometry and evolution of a mid-crustal extensional fault system: Chemehuevi Mountains, southeastern California, in Continental Extensional Tectonics,edited by M.P. Coward, 
J.F. Dewey, and P.L. Hancock, Geol. Soc. Spec. Publ. London 28, 313-335, 1987.

Lister, G.S., and G.A. Davis, The origin of metamorphic core complexes and detachment faults formed during Tertiary continental extension in the northern Colorado River region, U.S.A.,

J. Struct. Geol., 11, 65-94, 1989.

McGarr, A., and N.C. Gay, State of stress in the Earth's crust, Annu. Rev. Earth Planet. Sci., 6, 405-436, 1978.

McGarr, A., On the state of lithostatic stress in the absence of applied tectonic forces, J. Geophys. Res., 93, p. 13,609-13,617, 1988.

Nielson, J.E., and K.K. Beratan, Tertiary basin development and tectonic implications, Whipple detachment system, Colorado River Extensional Corridor, California and Arizona, J. Geophys. Res., 95, 599-614, 1990.

Ramberg, H., Gravity, Deformation, and the Earth's Crust, Academic Press, New York, 1981.

Ramsay, J.G., Folding and Fracturing of Rocks, McGraw-Hill, New York, 1967.

Rehrig, W.A., and S.J. Reynolds, Geologic and geochronologic reconnaissance of a northwest-trending zone of metamorphic core complexes in southern and western Arizona, in Cordilleran Metamorphic Core Complexes, edited by M.D. Crittenden, Jr, P.J. Coney, and G.H. Davis, Mem. Geol. Soc. Am., 153, 131-157, 1980.

Reynolds, S.J., and J. E. Spencer, Evidence for large-scale transport on the Bullard detachment fault, west-central Arizona, Geology, 13, 353-356, 1985.

Sibson, R.H., Fault zone models, heat flow, and depth distribution of earthquakes in the continental crust of the United States, Bull. Seismol. Soc. Am., 72. 151-161, 1982.

Smith, R.B., Unified theory of the onset of folding, boundinage, and mullion structure, Geol. Soc. Am. Bull., 86, 1601-1609, 1975.

Smith, R.B., Formation of folds, boundinage, and mullion structure, Geol. Soc. Am. Bull., 88, 312-320, 1977.

Smith, R. B., The folding of a strong non-Newtonian layer, Am. J. Sci., 279, 272-287, 1979.

Sonder, L.J., P.C. England, B.P. Wernicke, and R.L. Christiansen, A physical model for Cenozoic extension of western North America, in Continental Extensional Tectonics, edited by M.P. Coward, J.F. Dewey, and P.L. Hancock, Geol. Soc. , Spec. Publ. London 28, 187-201, 1987.

Spencer, J.E., Role of tectonic denudation in warping and uplift of low-angle normal faults, Geology 12, 95-98, 1984.

Spencer, J.E., Miocene low-angle normal faulting and dike emplacement, Homer Mountains and surrounding areas, southeastern California and southernmost Nevada, Geol. Soc. Am. Bull., 96, 1140-1155, 1985.

Spencer, J.E., Origin of folds of Tertiary low-angle fault surfaces, southeastern California and western Arizona, in MesozoicCenozoic Tectonic Evolution of the Colorado River Region, California, Arizona, and Nevada, edited by E.G. Frost and D.L.
Martin, pp. 123-134, Cordilleran Publishers, San Diego, Calif., 1982.

Spencer, J.E., and S.J. Reynolds, Relationships between Mesozoic and Cenozoic features in west central Arizona and adjacent southeastern California, J. Geophys. Res., 95, 539-555, 1990.

Stewart, J.H, and D.S. Diamond, Changing patterns of extensional tectonics in western Nevada: Overprinting of the basin of the Miocene Esmerada Formation by younger structural basins, in Continental Extensional Tectonics Near the Latitude of Las Vegas, Nevada, edited by B. Wernicke, Mem. Geol. Soc. Am., 176, 441-475, 1990.

Timoshenko, S.P., and J.M. Gere, Theory of Elastic Stability, McGraw-Hill, New York, 1961.

Timoshenko, S., and S. Woinowsky-Krieger, Theory of Plates and Shells, McGraw-Hill, New York, 1959.

Vening Meinesz, F.A., Les Grabens Africans resultant de compression ou de tension dans la crôute terrestre?, Inst. R. Colon. Belge Bull., 21, p. 539-552, 1950.

Weissel, J.K., and Karner, G.D., Flexural uplift of rift flanks due to mechanical unloading of the lithosphere during extension, $J$. Geophys. Res., 94, 13,919-13,950.

Wernicke, B., Uniform-sense normal shear of the continental lithosphere, Can. J. Earth Sci., 22, 108-125, 1985.

Wernicke, B., Axen, G.J., On the role of isostacy in the evolution of normal fault systems, Geology, 16, 848-851.

Wernicke, B., J.D. Walker, and M.S. Beaufait, Structural discordance between Neogene detachments and frontal Sevier thrusts, central Mormon Mountains, southern Nevada, Tectonics, 4, 213-246, 1985.

Wernicke, B.P., R.L. Christiansen, P.C. England, and L.J. Sonder, Tectonomagmatic evolution of Cenozoic extension in the North American Cordillera, in Continental Extensional Tectonics, edited by M.P. Coward, J.F. Dewey, and P.L. Hancock, Geol. Soc. ,Spec. Publ. London 28, 203-221, 1987.

Wilson, G., 1953, Mullion and rodding structures in the Moine Series of Scotland, Proc. Geol. Assoc., 64, 316-330, 1953.

Yin, A., Origin of regional, rooted low-angle normal faults: A mechanical model and its tectonic implications, Tectonics, 8 , 469-482, 1989a.

Yin, A., Role of buckling in formation of the doubly plunging antiformal/synformal geometry of detachment faults: a 3-D thin plate model, Geol. Soc. Am. Abstr. Programs, 21, 354, $1989 b$.

Yin, A., and J.F. Dunn, Mid-Tertiary structural and stratigraphic evolution of the Whipple-Chemehuevi detachment fault system, northern Whipple Mountains and central Chemehuevi Valley, southeastern California, Geol. Soc. Am. Bull., in review.

A. Yin, Department of Earth and Space Sciences, University of California, Los Angeles, California 90024-1567.

(Received July 3, 1990;

revised January 17, 1991, accepled April 2, 1991.) 